Book Reviews, Relegere: Studies in Religion and Reception 6, no. 2 (20I4): 24I-94.

(c) BY-NC-ND This work is licensed under a Creative Commons Attribution Non-Commercial No Derivatives 3.o License.

Relegere: Studies in Religion and Reception is an independent, open-access academic journal dedicated to the promotion and dissemination of innovative research in reception history, broadly conceived, within and across religious traditions.

www.relegere.org

ISSN I I79-723 I 


\section{Book Reviews}

Eric Repphun

The Cult of Emptiness: The Western Discovery of Buddhist Thought and the Invention of Oriental Philosophy, by Urs App . . . . . . . . 243

Carol A. Newsom

The Testament of Job: Text, Narrative and Reception History, by Maria Haralambakis . . . . . . . . . . . . . . . 248

Andrew Brown

Hidden Truths from Eden: Esoteric Readings of Genesis I-3, edited by Caroline Vander Stichele and Susanne Scholz . . . . . . . . . 25 I

Michael J. Kok

Peter in Early Christianity, edited by Helen K. Bond and Larry W. Hurtado . . . . . . . . . . . . . . . . 256

Chance Bonar

The Ancient Near East in the Nineteenth Century: Appreciations and Appropriations, 3 vols., by Kevin McGeough . . . . . . . . 26I Joseph M. Spencer

The Bible, Mormon Scripture, and the Rhetoric of Allusivity, by Nicholas J. Frederick . . . . . . . . . . . . . . . . . . . . 269

Anthony C. Swindell

The Gospel According to the Novelist: Religious Scripture and Contemporary Fiction, by Magdalena Mączyńska . . . . . . . . . . 274 


\section{Jim West}

The People's Book: The Reformation and the Bible, edited by Jennifer Powell McNutt and David Lauber . . . . . . . . . . . . . 276

Daniel N. Gullotta

A New Gospel for Women: Katharine Bushnell and the Challenge of Christian Feminism, by Kristin Kobes Du Mez . . . . . . . . 280 Koowon Kim

The Bad Jesus: The Ethics of New Testament Ethics, by Hector Avalos 283 Nikolai Blaskow

Nietzsche Versus Paul, by Abed Azzam . . . . . . . . . . . . 287 


\section{The Cult of Emptiness: The Western Discovery of Buddhist Thought and the Invention of Oriental Philosophy, by Urs App}

Kyoto: UniversityMedia, 20 I 2 | 304 pages | ISBN: 978-3-90600009-I (hardcover) \$40.76; ISBN: 978-3-906000-I 2-I (softcover) $\$ 27.90$

Urs App's The Cult of Emptiness is precisely what a scholarly book should be. It is faultlessly researched, clearly argued, engagingly written, and intellectually challenging. It is also what we might wish more books — of any kind — would be, in that it is often laugh-out-loud funny, deeply in tune with the glorious perversity of human history. The story it tells is at turns genuinely appalling and utterly delightful. In narrating the earliest European encounters with Buddhism and Buddhist philosophy, App holds up a brutally unflattering mirror to commonly held ideas about the world we live in (and how it come to be this way) and shows just how flawed those ideas really are.

He has a fine narrative sense, a keen eye for the telling detail, and a wickedly dark appreciation for the absurdity of it all. At times, the whole story of the initial contact between the West, in the form of Jesuit missionaries, and Japanese Buddhism, represented by a scattering of monks, politicians, writers, and a fugitive murderer, comes across rather like a series of pratfalls, mistaken identities, and wilful misunderstandings, a bit like a Shakespearean comedy but less eloquent and with far greater historical importance, more like a tragically consequential episode of Three's Company. Buddhist monks turn Buddhist philosophy into Christian theology. Christian missionaries turn Christian theology into what they thought was Buddhist philosophy and equate what they saw as the essence of Buddhism with tales from the Hebrew Bible. Even if some of this misunderstanding was wildly creative, a great deal of detail, nuance, and sense was simply lost in translation, and App argues convincingly that we are still struggling to get it all back, even hundreds of years later.

At the same time that it casts a wry, often amused glance at a complicated historical milieu, this is a serious and deeply reflective book. App grapples with fundamental questions of methodology and the place of scholarship within the larger culture, but interweaves this discussion so deftly with the 
rest of his analysis that it is never a self-important navel-gazing distraction, a common failing of too many academic books in the twenty-first century. App begins by arguing that the subject has not been given the proper scholarly attention:

Whereas the discovery by Europeans of the continents of our earth has been the subject of countless studies and its protagonists (such as Columbus) are universally known, research on the European discovery of our globe's "spiritual continents"-its religions and philosophies-is still in its infancy. The Christian West's discovery of Asia's largest religion and fount of philosophies, Buddhism, is a case in point: though it triggered one of the most significant spiritual and cultural encounters in world history, even the most basic questions remain unanswered. (I)

These questions, he notes, are fundamental given that the European invention of an imagined "Oriental religion" played "a crucial role in the premodern European perception of Asia and the genesis of modern orientalism" (3). These are matters, then, of some consequence, not mere historical footnotes. This act of perhaps unwitting invention saw the erasure of nuance and complexity; what emerged instead was the reductive notion of a single "Oriental philosophy," which, while not entirely fanciful, robbed Buddhism-to say nothing of Taoism, Jainism, Confucianism, and other Asian traditionsof much of its depth, its profundity, its difficulty, and ultimately its humanity. It also served to foreground a single aspect-the concept of $m u$, usually translated as "emptiness" - of a single form of Buddhism-monastic, aristocratic Japanese Zen-at the expense of all of the myriad other forms the tradition has taken in its long history.

The first chapter, aptly titled "Translation Hazards," takes the reader back to I 55 I's publication of the first Chinese-character document published in Europe, which detailed the donation by a group of monks of a Buddhist temple to Jesuit missionaries. There were mistakes from the earliest moments of contact. Both sides went looking for ways to make sense of new and unfamiliar ideas, falling back on the old and the familiar: "It is entirely fitting that the story of the Western discovery of Buddhism and the invention of a single 'Oriental philosophy' should begin with a fiasco involving the Arlecchino mechanism: Arlecchino is a main character of the Italian commedia 
dell'arte who thinks that the whole world is exactly like his family and acts accordingly" (I I).

This earliest textual encounter between Buddhism and the west shows the power of this Arlecchino mechanism on the Japanese side as "the Jesuits appear as representatives of Buddhism who inherit a Buddhist temple in order to promote the Buddhist religion" (I6). In turn, the Europeans, who first translated (to use the term generously) this document, hardly fared better, removing references to Buddhism in favour of vague terms such as "the law that produces Saints" (I6). As later chapters reveal, this sort of thing plays havoc with the documentary record, given that many important sources exist only in translations into Portuguese, Spanish, Latin, and Italian: "All we have at our disposal are reports showing how the missionaries understood what was said" (23).

The small Jesuit mission in the 1550 in Japan was beset by difficulties with Buddhist terminology and philosophy- "Some Zen adepts denied just about everything the Jesuits happened to affirm while others claimed that the Jesuits' teaching of Deos is identical with their doctrine" (33) — which led the missionaries to search for clarity in their ceaseless drive to win converts and spread Christian doctrine to a new and largely unknown land. Already by I 556, these missionaries were treating Buddhism as a "religion," and one distinct from Shinto, a separation that has a long and ideologically charged history both inside and outside of Japan. Crucially for App's central argument, these earliest missionaries wrote also of another separation, between the "outer" doctrines of Buddhism, including the existence of various deities as well as the Pure Land and various darker versions of an afterlife, which they argued that the monks taught to the laity (but did not themselves believe) and a purer "interior core of their law" that comprised the authentic heart of Buddhist doctrine (36).

This doctrine was profoundly atheistic and denied the existence of a soul or any form of an afterlife. It is this imagined inner essence that was to take root in European consciousness in the intervening centuries. This doctrine, profoundly this-worldly as it is, was compared by the missionaries to "the poison of the old serpent" from Genesis. The idea of emptiness that comprised the "inner" doctrine of Buddhism was thus understood in the light of what the Jesuits already understood about their own religion: "Arlecchino thus once more plays his trick: the Jesuits interpreted the unfamiliar philosophy in terms of what they were familiar with" (43). Again, App finds the mechanism at work in complex ways: "The Arlecchino effect was obviously 
at work not only for the Jesuits but also for the Japanese: each group detected in the other what it was already familiar with" (5I). The missionaries leaned on Greek and Latin philosophers and even more heavily on Aquinas and orthodox Christian theology, filtering their entire picture of Buddhism and Buddhist thought through these lenses:

Shaka's [the Buddha's] ultimate teaching thus fits the pattern that students of scholastic philosophy had learned to identify as typical of ancient Greek and Roman atheism: the denial of an omnipotent and omniscient creator God in favor of an eternal chaos or materia prima from which all beings, like waves in water, arise by chance only to eventually dissolve again into chaos in an endless cycle of birth and death. (45-46)

With a painstaking analysis of a vast, multi-lingual documentary record, App demonstrates convincingly that, although these earliest Christian writings about Buddhism were read almost solely by other missionaries, they nonetheless had a profound and lasting influence because such writings informed later works on Buddhism published widely in Europe. As the centuries passed, the local-Japanese Zen-became universal, while obscure missionary documents intended for other missionaries became the vehicle for widely accepted conceptions of an imagined East just beginning to permeate European consciousness at the very dawn of the modern age.

The second half of the book moves into the seventeenth century, as the earliest encounters between European missionaries and Buddhists in Japan continued to influence a growing, popular fascination with Buddhism and Buddhist thought in Europe. Portuguese Jesuits began an attempt to fit Buddhism and other Asian traditions into biblical understandings of history, still dominant in early-modern European thought. One influential writer concluded, in the I620s, for example, that the Chinese "seem to be descendents of Ham, because he held similar errors and taught them to his descendents, who then took them with them when they set off to populate the world" (IOI). Later commentators would then link Ham with Zoroaster, thereby bringing another set of religious traditions into the historical world of the Bible, regardless of the vast differences between the disparate traditions so casually thrown together. Still later writers would link all of the religious "errors" of Asia to an imagined "cult of the ancient Egyptians" (I24). The Buddha was thus assimilated not only to Jupiter, but also to Osiris. Thus, 
App argues, these writers painted a picture of "Asian religions and philosophies of branches of a single root-heresy" and "posited a fundamental unity of doctrine not only embracing much of Asia, but also the Greek and Roman world" (I27). The Buddha's "inner doctrine" also later became a way of attacking more native European movements, such as Spinozism: "The association of worrisome European movements with China's most detestable doctrine ... was an elegant and effective way of attacking such movements" (I78).

Throughout, App's linguistic skills and breadth are astonishing, even for a writer who has lived and worked in Asia for much of his career. He deals with original reports from missionaries written in Portuguese, Spanish, Italian, and Latin. He also translates or re-translates primary source materials in Japanese and Chinese. Throughout The Cult of Emptiness, App traces these complex chains of influence with a series of helpful flowcharts that help to make sense of the flood of names and terms that may be daunting to any reader less well versed than the author, which, I have to imagine, would be most of them. Drawing often on materials from his own personal library, from which he also takes much of the most telling textual evidence, he also presents an intriguing and at times very amusing pictorial history of these ideas and the way they travelled through time and over vast distances. As the book draws to a close, App demonstrates the vast and varied influence of these ideas in later centuries:

Once it had taken root and begun to bloom on European soil, the beguiling perfume of the flower of the imagination called "Oriental philosophy" was to waft through the entire eighteenth century, persistent like musk and clinging like patchouli. It enthralled church historians like Mosheim, historians of philosophy like Brucker, encyclopaedists like Diderot, and even famous orientalists like Jospesh de Guignes and Anquetil-Duperron. Hegel's lecture on Asia of the I 820 , French debates about Buddhism's "cult of nothingness" in the I 850 , and countless discussions of the meaning of "nirvana" in the nineteenth and twentieth centuries still exuded its unmistakable, intoxicating scent. (237)

The Cult of Emptiness serves as a case study for just how deeply Christian texts, ideas, and systems of categorisation are ingrained in the history of 
the Western world, and just how far-in terms of both distance and timescholars and historians have to go to uncover this influence. We will perhaps never free ourselves from such influences, as they are the warp and weft of our picture of history, but App shows us that it is worth the effort. At the same time as he uncovers these hidden chains of influence, reading, and re-reading, App hammers home his central —if unstated — thesis: bad ideas have wings. They travel. They persist. They even thrive. But that doesn't mean we have to like them.

On an entirely different matter, this review is to be my last as sometime co-editor and co-founder of Relegere, as academia and I have largely parted ways, and not entirely amicably. My thanks to our readers, our contributors, and especially to James, Deane, and Will for the opportunity to be a part of a rigorously independent venture and the chance to do some work I can be truly proud of (now that I am an ordinary citizen again, I re-claim the right to end sentences with a preposition). I wish them-and you, Constant Reader-the best of luck in the future.

Eric Repphun

Independent

\section{The Testament of Job: Text, Narrative and Recep- tion History, by Maria Haralambakis}

London: Bloomsbury T\&T Clark, 20 I 2 | viii + 240 pages | ISBN: 978-0-567-57558-6 (hardcover) \$136.00; ISBN: 978-0-56754164-2 (softcover) \$37.95

For a work of such intrinsic interest, the Testament of Job has been comparatively neglected in scholarship. Most likely, the reason is that a significant part of the

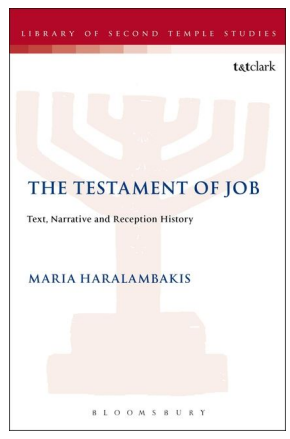
manuscript tradition is in Slavonic, a language that is itself under-represented in graduate education in biblical studies and the history of Christianity. Thus the field has every reason to be grateful when a scholar such as Maria Haralambakis not only brings significant linguistic skill but also careful analytical judgment to bear on important issues concerning this work and the way it has been received in medieval Christianity. 
Haralambakis's work is a revision of her doctoral thesis, supervised by Prof. George Brooke of the University of Manchester. Although the book is quite wide-ranging (perhaps too wide-ranging), its major contribution is in its treatment of the Slavonic manuscript tradition and in its redirection of attention away from the attempt to reconstruct an "original" version of the Testament of Job and towards attending more carefully to what the individual manuscripts can tell us about how the Testament of Job was read and received in the Coptic, Greek, and especially Slavonic traditions.

Following a review of recent research in Chapter I, Chapter 2 provides substantial information on each of the major manuscripts, focusing not just on the text of the Testament of Job itself but on the contents of the other works included in those manuscripts, as well as any other features of significance. This codicological focus represents an important new direction, though Haralambakis is cautious in drawing conclusions about what can be said about the Testament of Job from the company it keeps. In previous scholarship more attention has been given to the fourth-century Coptic manuscript and to the Greek manuscripts, so Haralambakis focuses on the nine Slavonic manuscripts. In addition to general information, she provides a selection of textual variants, organized as case studies (see Appendix A), a diplomatic edition of the first five chapters (see Appendix B), and a translation of the Slavonic Testament of Job (see Appendix C). She concludes that the Slavonic manuscript tradition is less homogeneous than it has typically been characterized, though it appears that the Testament of Job was translated from the Greek only once. Some of the differences from the Greek reflect an attempt to improve the story.

Chapters 3 and 4 focus on literary issues: structure, genre, and narratology. In my opinion these are the least satisfying portions of the book, though certainly not without value. Haralambakis provides an extremely detailed structural outline for the Testament of Job and provides extensive justifications for her analysis of the structure. Though the analysis supports her contention that the book is not a mish-mash to be explained through clumsy editing together of sources, it is not clear to me that the conclusion requires so much sometimes tedious discussion. Similarly, the discussion of genre, and of the various suggestions made by previous scholars, serves largely to demonstrate how poorly biblical scholarship has dealt with the notion of genre. In my opinion, Haralambakis underappreciates the value of understanding the Testament of Job through the lens of testament. Her own preference is for "example story." She actually provides more nuanced in- 
sight into the way genre functions in a later chapter, when she attempts to discern the narrative conventions by which medieval audiences were reading the work-likely as hagiography. The concept of genre may function in many ways: as a template for an author attempting to compose a certain sort of writing, as a reference point for a reader attempting to figure out what sort of thing one is reading, or as a tool for a critic attempting to devise a pragmatic way of grouping and sorting texts for particular purposes. Sorting out which of these notions one is working with is a good first step towards making the term useful.

Haralambakis's narratological analysis in Chapter 4 does provide a welcome rebuttal of older critics who denigrated the Testament of Job and explained its apparent deficiencies as evidence for clumsy composition and redaction from a variety of component sources. Instead, Haralambakis makes a strong case for the sophistication of its various narratological strategies, especially the complex use of embedded narrative. More disappointing is the very superficial treatment of character, which only briefly discusses Job and completely neglects the fascinating characters of Job's wife and Satan, not to mention the radical reworking of the character of Elihu. In these chapters, I think one sees the problem of focus that afflicts the book. Is it a study of manuscript traditions and what one can learn about reception through studying each manuscript? Or is it an attempt to study the story of the Testament of Job? It is too much to attempt both. The literary aspect is, at any rate, shortchanged in the process.

Chapter 5 returns to the focus on manuscripts and reception. Haralambakis reviews the attempts to characterize the function of the original composition (i.e., as devotional literature, missionary literature, martyr literature) and finds them all problematic, though they do point to features in the text that facilitated its being read as such literature in later contexts of reception. While it is not possible to say much regarding how the Testament of Job was read in the Coptic context, Haralambakis makes a cautious but persuasive case that in the Byzantine and later Eastern Christian contexts "the Testament of Job came to be perceived as a kind of saint's life" (I 5 I). Although, as she notes, hagiography is a varied type of literature, she demonstrates an impressive number of similarities between features in the Testament of Job and those that regularly appear in narratives of saints' lives. Some changes in the Slavonic textual traditions as compared with the Greek also suggest an assimilation of Job to the norms of hagiography. The manuscripts within 
which the text is preserved are not definitive, however, for indicating how the narrative was understood.

Chapter 6 surveys the conclusions of the work and suggests directions for further research. Though in my opinion the work would have been even better if Haralambakis had minimized the aspects of literary analysis and devoted the space and attention to further issues in the codicology of the Slavonic tradition and the evidence for reception in the Eastern Church, one has to conclude with admiration and appreciation for what she has accomplished. One hopes that she will continue her work both with the Testament of Job and more broadly with Jewish pseudepigraphical works that were preserved and developed in Slavonic literature.

Carol A. Newsom

Emory University

\section{Hidden Truths from Eden: Esoteric Readings of Genesis I-3, edited by Caroline Vander Stichele and Susanne Scholz}

Semeia Studies 76 | Atlanta: SBL Press, $2014 \mid 298$ pages | ISBN: 978-I-62837-013-3 (hardcover) \$51.95; ISBN: 978-I-62837o I 2-6 (softcover) $\$ 36.95$

Stichele and Scholz, the editors of this volume, who

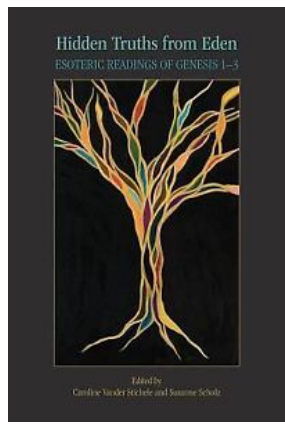
hail from institutions on the eastern and western sides of the Atlantic respectively, express a remedial agenda for their volume. Their feeling is that the dominant historical-critical paradigm in biblical studies has sidelined the reading of the Bible for its "spiritual" sense, despite the deep heritage of such reading within and without the Christian church. More specifically, with exceptions such as Elaine Pagels's research in early Gnosticism, "the historicized quest of biblical meaning" has involved "a broad disregard for studying the extensive interpretation history of esoteric readings of the Bible" (vii). Their hope is that this collection of essays investigating a range of esoteric interpretations of Genesis $\mathrm{I}-3$, ancient and modern, might assist "esoteric bibli[c]al readings [to] become part of the academic discourse in biblical studies," befitting the "post-postmodern period" in which we live 
(let's hope that's the last "post") and bringing a corrective to "the literalist malady" (viii).

Noting the fraught definition of "esoteric" in their introduction, Stichele and Scholz explain the term etymologically as a hermeneutic that is concerned with the inner life of the reader, and we might add that it suits the idea of an inner or hidden meaning of the text equally well (2). The addition of examples is helpful. Seeing the mention of "alchemy, astrology, Anthroposophy, Gnosticism, Neoplatonism, Rosicrucianism, or Christian Theosophy," along with names such as Jacob Böhme, Emanuel Swedenborg, Helena Blavatsky, and Rudolph Steiner will help most readers gain some sense of the phenomenon under discussion, however blurry the boundary that embraces them. As the examples indicate, the focus is on Western and Judeo-Christian esoteric examples. The volume therefore embodies a twofold aim: I) to introduce esoteric hermeneutics "to the academic field of biblical studies" and prompt corresponding studies of other biblical texts, and 2) "to awaken interest in esoteric perspectives, methodologies, and thinkers" (3). We may readily class this set of studies within the broader contemporary field of reception history, recognising in this work the latter's attraction to streams of interpretation that have suffered neglect or positive repression under modern research models or traditions.

The collection is structured in four sections following the introduction, the first three of which correspond to three broad historical periods: the late antique or patristic period, the middle ages through the Renaissance, and finally the eighteenth through the twentieth centuries. The fourth section consists of two responses from respected scholars of esotericism, whose effect is very much to flavour the reader's final impressions from the book.

In part I, the first essay by Anna Rebecca Solevåg offers an interpretation of the apocryphal Acts of Andrew, dating from about the 2 nd- 3 rd century CE (9). Solevåg helpfully clarifies the definition of esotericism ( 10 ), then studies the Acts of Andrew from both class and gender angles (I2), concluding that this text, historically interpreted as a call to sexual renunciation, is more fully understood in the broader category of esotericism (22-23).

Almost the defining text of ancient Gnosticism, the Apocryphon of John, elicits the second essay by Tuomas Rasimus. Current dispute over the meaning and viability of the term "Gnosticism" compels Rasimus to define it further, and he opts to "speak of Classic Gnosticism whose chief representative is the Apocryphon of John" (32). Rasimus asks why it is an eagle in this version of the story, rather than the serpent, that persuades Adam and Eve 
to eat from the Tree of Knowledge (35), finding that the eagle is a Roman imperial symbol for Christ.

The third essay in Part One examines Origen's interpretation of the "garments of skins" given to Adam in Eve in Gen 3:2I, late in the Eden narrative. Author Peter Martens succeeds in showing that Origen is drawn to the idea that a primordial, spiritual humanity is first "clothed" with human flesh at this point in the story (57), yet struggles for interpretive consistency, and has to dechronologize the passage to allow Gen 2:7 and Gen 3:2 I to refer to the "incarnation" of pre-existing human souls (67-70). We feel prompted to ask the taxonomic question once again: "Is Origen also among the Gnostics?"

Part 2, "Zoharic, Kabbalistic, and Alchemical Speculations," is inherently broad, and opens with an essay by Elliot R. Wolfson focusing on how gender is presented in the Zohar, the defining text of Jewish kabbalah mysticism, emerging from late medieval Spanish Judaism and showing connections to earlier rabbinic speculation (87). Jewish kabbalah includes the core belief that the most basic entities of reality "are the manifold permutations of the twenty-two Hebrew letters, themselves enfolded in the Tetragrammaton, identified as the mystical essence of the Torah" (94). Wolfson here rejects the sympathetic view that the Zohar embodies a truly balanced valuing of male and female, instead finding it androcentric ( $\left.\mathrm{IO}_{3}-4\right)$. More relevant to me was Peter J. Forshaw's essay on the incorporation of kabbalistic mysticism into Italian Renaissance Christianity, particularly through the prodigious, though short-lived, Pico della Mirandola (I463-I 494). Forshaw reveals the way the letters of the very first word of the Hebrew Bible, בראשית, were understood to communicate hidden realities; Mirandola turned this stock kabbalistic device in a loosely Trinitarian Christian direction (I28-I 30). Mirandola epitomizes the ongoing esoteric fascination with the opening chapters of Genesis, perceived as cryptic repository of the universe's secrets (I32), in an essay that helped this reader better understand the flow of the history of esoteric thought in the West.

A less kabbalistic than Neoplatonist and perhaps Pseudo-Dionysian emanationism appears in the treatise Philosophia ad Atheniensis, treated in the next essay by Georgiana Hedesan. The Philosophia ad Atheniensis was attributed early on to the founding figure of early modern alchemical philosophy, Paracelsus ( I 493-I 54I), though the attribution is now debated. "The key to Ad Atheniensis's understanding of creation lies in the uncreated mysterium magnum ('great mystery') used by God to make the world," Hedesan explains (I 47). The mysterium magnum appears to combine the passive role 
of primordial, formless matter with an active role akin to Philo's Logos as an agent of creation. Though "the vision of Ad Atheniensis is fraught with paradoxes," it had in common with other such esoteric interpretations the quest for "an invisible Genesis lying with the written one" (I 54) Hedesan's explanation helped clarify the use of Mysterium Magnum as the title of a famous esoteric work by the influential mystic Jakob Böhme (I 575?-I624). Having read the latter work, I strongly recommend reading an introduction like Hedesan's before tackling the primary documents.

Part 3's opening essay follows on smoothly from the two preceding essays. Here one of the editors, Susanne Scholz, studies "Esoteric Interpretations of Gen I-3 by E. Swedenborg, R. Steiner, and S. D. Fohr," thus touching on each century from the eighteenth up to the present day. Their post-mortem neglect by mainstream scholarship exemplifies, in Scholz's mind, the sidelining of influential esoteric interpretations of Genesis in academic biblical studies. She is drawn to Swedenborg's view that "spiritual understanding is the exclusive goal of biblical exegesis," in contrast to "the dominant historicalliteral paradigm" (I70-7I). Steiner's influence persists in the Steiner schools that are still dotted around the Australian landscape at least; I have lived within walking distance of one in each of my last two homes. Samuel D. Fohr's "esoteric reading of Gen 2-3" ( I 86) provides a link between past and present, since Fohr is author of the final essay in the volume.

The final two essays in part 3 are narrower in scope. First, László-Attila Hubbes offers a study of the philosophy of the original purity, fall and ultimate restoration in the thought of eclectic Hungarian thinker Béla Hamvas (I 897-I 968). Hubbes admits that the connection with Genesis I-3 is only indirect (204), and it stretches the volume title's implied scope. Hamvas appears to have melded gnostic, kabbalistic, and classical philosophical ideas into a quasi-Christian redemption myth that envisions a restored golden age (2 I 2-I 5). Then Hugh R. Page, Jr. sets out in the following essay to initiate a program for the study of African and Diaspora African esotericism. He expresses his aim "to start a scholarly conversation" in a barely touched field, though he has to admit that the connection with Gen I-3 remains to be explored (229-30), a deficit that throws in even greater doubt whether this essay has a clear claim to membership in the collection.

The Responses in Part Four have a kind of meta role in relation to the preceding nine essays. The first, Elaine Pagels's "Strategies of Esoteric Exegesis," reads rather like the editorial preview found in many edited volumes, but with a more practised eye than most. Pagels's own expertise is oriented 
towards the ancient part of the volume's historical sweep, but she identifies themes recurring in esoteric interpretations across the centuries spanned, such as the androcentric undertones thwarting the superficial male-female dualism in many esoteric interpretations (240), and the dispersal of Jewish mystical ideas into subsequent Christian sources (243-44). Resisting Scholz's disillusionment, Pagels retains a place for investigation of "the political, social, and historical circumstances and concerns of each exegete and of the audience each addresses," i.e. for historical-critical investigation (244).

Finally, Samuel D. Fohr's "Esotericism and Biblical Interpretation" is a both-sides or both-emic-and-etic study, after Fohr's esoteric material itself formed a subject for investigation earlier in the book (I86-I9I). This essay reflects the well-schooled thinking of a mind steeped in the material at hand, along with subtle signs of an insider's commitments. He is willing to be critical of the preceding essays, e.g., criticizing Hugh Page for equating "esoteric" with "occult," whereas he considers that "the first deals with the spiritual while the second deals with the worldly" (262). And he too, like Pagels, retains a place for historical criticism (266). For the purpose of understanding esotericism, though, you might find his characterization thought-provoking:

In the exoteric approach, God is up in the heavens, while we are down here on earth, and our goal is to be loving servants who will finally meet God in heaven after we die. In the esoteric approach, we are nothing other than God, and the spiritual goal is to become aware of this.... From the exoteric point of view, God is in the world, in heaven, while from the esoteric point of view the world is in God. (247)

Such nutshell statements are vulnerable to being simplistic and one might feel that there are other theological-philosophical possibilities. The following context adds nuance to this nonetheless provocative twofold antithesis. Fohr's essay, and the collection as a whole, have the value of drawing scholarly attention to what does remain, still, an undeservedly isolated and neglected tradition within the study of biblical reception. Esoteric traditions from second-century Gnosticism through medieval kabbalism to Rudolf Steiner and beyond have both been consistently attracted to the power and pregnant imagery of the early chapters of Genesis, in particular the Eden narrative of Gen. 2:4-3:24, and have regularly reasserted their influence on popular, 
scientific, and religious thought and culture. For these reasons alone they deserve the attention they receive in this book. Its content is selective, and much ground remains to be turned over, but this volume is a stimulating beginning.

Andrew Brown

Melbourne School of Theology

\section{Peter in Early Christianity, edited by Helen K. Bond and Larry W. Hurtado}

Grand Rapids: Eerdmans, 2015 | 380 pages | ISBN: 978-0-80287I 7I-8 (softcover) \$40.00

The Centre for the Study of Christian Origins at the University of Edinburgh hosted a conference on the apostle Peter during July 4-6, 2013. Since I had the

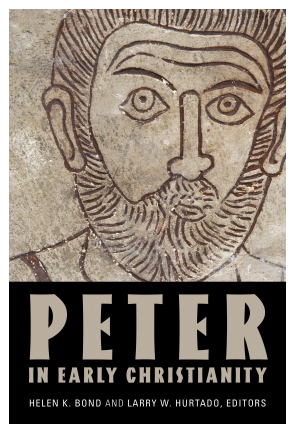
privilege of attending it, I am pleased to review the fruit of the scholarly labours that went into producing this volume. In their editorial introduction, Helen K. Bond and Larry W. Hurtado clarify the rationale for this conference: "After years of playing second fiddle to Paul, Peter has been the focus of a number of scholarly works over the last decade, and so it seemed like an opportune time to gather together an international team of experts to reconsider the apostle and his legacy within the early church" (xvi). The book is divided into three main sections, covering the historical Peter, canonical traditions, and non-canonical traditions about him.

The book opens and closes with essays on Peter's reception among Protestant and Catholic exegetes respectively. In the first essay, Hurtado reviews the seminal studies on Peter by Oscar Cullmann, Martin Hengel, and Markus Bockmuehl. Although they stop short of endorsing the papacy as Peter's authoritative successor, Hurtado displays the ecumenical interests driving their research from the exegesis of specific texts (e.g. Matt I6:17-19) to the larger picture of Peter as an apostolic pillar who acted as a centrist figure between the faction advocating Gentile Judaizing and Paul. In the final essay, Bockmuehl enters into critical dialogue with the Catholic theologian Hans Urs von Balthasar. Von Balthasar defends the pastoral and juridical functions of the Petrine office, yet insists that it must not be exalted above other apos- 
tolic "charisms" like the Jamesian ideal of tradition, the Johannine ideal of love, and the Pauline ideal of spiritual freedom. Though Bockmuehl critiques the reduction of Peter to an ecclesiastical cipher, he maintains that the task entrusted to Peter of building up the church and pastoring the flock (Matt I6:17-19; Luke 22:31-32; John 21:15-17) has not expired as long as the flock endures.

In the first section, Sean Freyne draws on literary and archaeological data on sites such as Tarichea and Bethsaida/et-Tell to reconstruct the fishing industry in Galilee. Margaret Williams brings Jewish onomastic practices to bear on the name "Simon bar Yonah" and the supernomen rendered in Aramaic as Kepha and Greek as Petros. She contends that Jesus bestowed the Aramaic epithet on Simon, though its meaning was forgotten over time, against Bockmuehl's view that Simon was previously known by the Greek nickname in Bethsaida. Bond offers a nuanced, non-apologetic case that Peter served as the evangelist Mark's informant. Peter's recollections were subject to the frailties of human memory and were conformed to the collective memories of the Roman Christ followers. She adds that the generic conventions of Mark's professional bios meant that the spotlight was on Jesus's public deeds, with little interest in Peter's musings about his private encounters with Jesus. Conceding that ancient historiographers either conveyed the gist of a speech, even if not at the verbatim level, or freely invented speeches, Jonathan W. Lo is adamant that the common elements of Peter's missionary proclamation are accurately summarized in the literary style of the author of Acts. Granted, Paul's speech in Acts I 3: I 6-4I contains similar elements and stresses the continuity of Paul's message with that of his predecessor, but Peter's preaching is generally distinctive from the other characters in Acts. Timothy D. Barnes interprets John 2 I: I 8-I9 to mean that Peter was dressed in a flammable tunic and burned alive in the cruciform position, corroborating Tacitus's report that Christians were set ablaze while affixed to crosses in a modified form of burning (Annals I 5.44.4).

The second section analyzes the New Testament portrayals of Peter. To explicate Peter's behaviour in the Synoptic tradition, from his antagonistic stance against Jesus's passion prediction to his nonsensical suggestion at the Transfiguration (Mark 8:32-33, 9:5-6 par), John R. Markley surmises that there is an apocalyptic motif at work which features "human imperception in the face of divinely revealed mysteries" (IOI, I03, I05, 108 [emphasis original]). Whereas the relationship between Peter and the Johannine Beloved Disciple is often construed in oppositional or complementary terms, Jason 
S. Sturdevant argues that it is the connection with Jesus which is the key to unlocking Peter's characterization in John's narrative. Jesus leads Peter on the path of discipleship, employing varied didactic methods to mold Peter's character so that he will become a shepherd who lays down his life for the sheep (John I0:I I-I 8; 21:18-I9). After highlighting Luke's redactional tendency to edit or omit Markan parallels denigrating Peter, Finn Damgaard ponders why Luke re-narrated Peter's denials. By turning back after his momentary lapse, Peter is qualified to preach repentance to his "brothers [and sisters]" who equally acted in ignorance in condemning Jesus (Luke 22:32; cf. Acts 3:I7). Sean A. Adams and Matthew V. Novenson underscore the precedent set by I Peter in representing Peter as possessing grapho-literacy and inspiring the production of additional pseudonymous Petrine epistles, but certain Christian writers struggled to reconcile this with the description of Peter as agrammatos or "without letters" in Acts 4:I3. The scribal Peter who delves into the biblical scrolls to confirm the gnosis (knowledge) about the deity's transcendence and the inadequacy of the temple cult resurfaces in William Rutherford's paper on the Preaching of Peter in the third section.

As for the third section, Todd D. Still lists the assessments of Peter as an apostle, pillar, witness, teacher, example, or letter writer in the Apostolic Fathers, yet marvels that the images of Peter as a rock, elder, missionary, shepherd, miracle worker, or holder of the keys are missing. Paul A. Hartog compares I Clement with Polycarp's Epistle to the Philippians; the former explicitly lifts up Peter as a model to be emulated (I Clem. 5.3-4; cf. Pol. Phil. 9. I-2) and the latter is indebted to I Peter for its paraenesis and exhortations. Tobias Nicklas explores the spectrum of "Gnostic" responses to Peter, from virtual neglect in writings of Sethian or Valentinian provenance to the validation of Peter as the principal recipient of revelation. Curiously, texts with sharply dissimilar views on Peter like the Gospel of Judas and the Epistle of Peter to Philip were read together in the same codex. Paul Foster surveys a wide range of "Apocryphal" gospels, acts, epistles, and apocalypses. Some texts embellish canonical episodes involving Peter or contribute to the hagiography surrounding Peter's miracles or martyrdom in Rome, while other texts depict Peter as promoting or disparaging post-Easter revelatory teachings. Foster concludes that these writers were not constrained by the memory of Peter, for "Peter" authorizes whatever ideologies are advanced in their texts. Paul Parvis traces Peter's transformation from the apostle who instituted a line of bishops at the See of Antioch to Antioch's original bishop. Lastly, Peter Lampe examines the archaeological and iconographic record for 
where Christians located Peter's burial site and for the popular veneration of Peter in Rome.

Bond and Hurtado should be commended for organizing an outstanding conference hosting several experts on various aspects of Peter's career and legacy. Space does not permit a full evaluation of all the diverse perspectives collected in this volume, so I will briefly engage with some arguments put forward about the canonical representations of Peter, the Papian tradition on the evangelist Mark, and the episcopacy of Peter in Rome. First, Bond and Damgaard rightly perceive that Peter's denials, like the memory of Paul as a former persecutor, could have performed a paraenetic function for Christ followers who recalled Peter's rehabilitation and years of service (59, I2829). Moreover, Peter's bewilderment may be a literary device that allows for Jesus to elucidate his teachings and parables. On the other hand, the hard-heartedness of the Twelve, presumably including Peter, in the Markan narrative (Mark 6:52; 8:I7-2I; contra Matt I4:33; I6:I2) seems to move beyond the motif of a seer's imperception and temporarily aligns them with the outsiders hardened against Jesus (Mark 3:5). At least in these pericopes, it is difficult for readers to empathize with the Twelve when they are repeatedly corrected about the same issue $(6: 35-37 ; 8: 2-4$, I4-2I). As for Peter's character arc in John's story, Sturdevant's reading may depend on whether one agrees with Paul S. Minear and Richard Bauckham that the Johannine epilogue is an integral part of the Gospel's narrative structure rather than an editorial addition ( I I 7, n. 27). Lo looks at criteria for detecting possible sources behind the Petrine speeches in Acts such as the presence of Semitisms or primitive Christological titles, but he may undercut some of these points by noting the rhetorical practice of ethopoeia or speech in character and dismissing the evolutionary Christology paradigm (69-73). His statement that "Luke was acquainted with Paul and other characters in his narrative" needs to be fleshed out (74).

As for Peter's role behind the composition of Mark's Gospel, Bond notes the reluctance of biographers, such as Tacitus (cf. Agricola 4.3; 22.4; 24.3), to refer to their sources or eyewitness testimony $(55, \mathrm{n} .23)$. This reluctance may still stand out from the total absence of any explicitly identified source in Mark's narrative, which also contrasts with a few other evangelists (cf. Luke I:I-2; John I9:35). It remains plausible that the evangelist may have consulted some eyewitness informants, but the idea that Peter was Mark's primary source rests on the testimony of the Elder John and Papias of Hierapolis (cf. Hist. Eccl. 3.39. I 5-16). Given their erroneous judgment that Matthew's 
logia was originally written in a Semitic language (Hist. Eccl. 3.39.16) and Papias's naïve acceptance of extravagant oral reports (cf. Irenaeus, Adv. Haer. 5.33.3-4; Eusebius, Hist. Eccl. 3.39.9; Apollinarus of Laodicea on Matthew 27:5), Papias's credibility may be open to question. Bond and Still also assign the tradition in Ecclesiastical History 2. I 5.I to Papias (46, I65-66), but it seems more likely to me that Eusebius loosely paraphrased a section from the Hypotyposes of Clement of Alexandria and asserted that Papias was in agreement with the basic sentiments expressed therein (Hist. Eccl. 2.15.2; cf. 6.1 $4.5-7)$.

A number of chapters interact with the textual witnesses for Peter's presence and martyrdom in Rome (e.g. John 2I:I8-I9; I Pet 5:I3; I Clem. 5.4; Ignatius, Rom. 4.3; Acts of Peter 37[8]; Gaius in Eusebius, Eccl. Hist. 2.25.7). Michael Goulder's article "Did Peter Ever Go to Rome" (2004) is a surprising omission. Only Barnes directs a few polemical remarks towards Otto Zweirlein's 2009 monograph Petrus in Rom, calling it the "nadir in historical criticism" and taking issue with Zweirlein's exegesis and "hypercritical" dating of the Ignatian epistles (86-87). Barnes's theory relies on the meaning of the verb zonnumi as girding oneself in contrast to the crucifixion of victims in the nude (77-80, 84-86), so I would be interested to see his response to the recent 2014 monograph Crucifixion in the Mediterranean World by John Granger Cook that discusses some limited evidence that crucified victims might wear some kind of loincloth or undergarment on pages 192-193. In the end, these critical observations are intended to stimulate further dialogue around these thought-provoking essays and should not detract from the fact that Bond and Hurtado have produced a must-read volume for all future studies of the apostle Peter.

Michael J. Kok

The King's University 
The Ancient Near East in the Nineteenth Century: Appreciations and Appropriations

I. Claiming and Conquering

II. Collecting, Constructing, and Curating

III. Fantasy and Alternative Histories

by Kevin McGeough

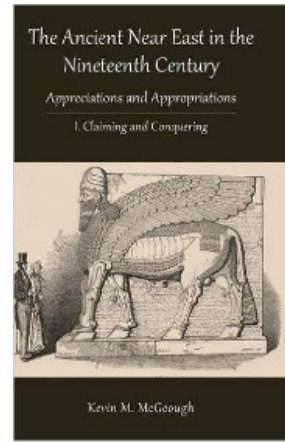

Hebrew Bible Monographs 67, 68, and 69| Sheffield: Sheffield Phoenix Press, 20I5 | xix + 457; xxv + 423; xxix + 43I pages | ISBN: 978-I-909697-65-2 (hardcover) £70.00; 978I-909697-66-9 (hardcover) £60.00; 978-I-909697-67-6 (hardcover) $£ 70.00$

University of Lethbridge professor Kevin McGeough presents a meticulous and thorough three-volume series on the reception of Near Eastern culture, history, and art in nineteenth-century Europe and America. Both in the introduction to the first volume and throughout the series, McGeough makes clear the fascination held by Western entities such as England, France, and the United States in relation to the geographically and temporally distant lands of ancient Egypt and Mesopotamia. McGeough summarizes the goals of this broad study in his introduction:

This study shall explore some of the ways that the ancient Near East, which at the outset of the nineteenth century was best

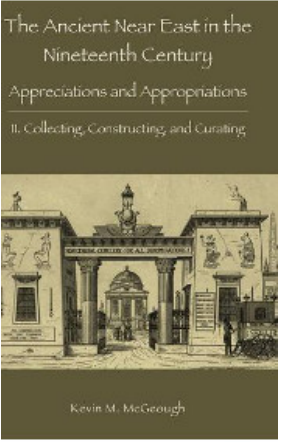

Ghe Ancient Near East in the nineteenth Century

Appreciations and Appropriations II. Fantasy and Filtemaxive Histories

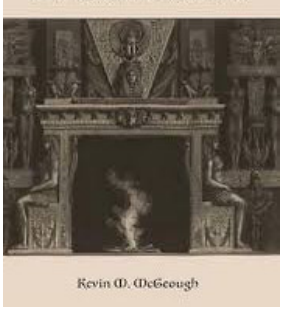
understood as a manifestation of elite culture, was adopted and revised in popular culture, how the scholarly significance of the ancient Near East was understood and adapted by producers and consumers of popular culture and how the growing popularity of this subject among the middle classes created new commercial prospects involving mummies, pyramids and biblical history. (I.8)

As he notes, the nineteenth century contains a plethora of catalysts for both elite and popular interactions with the ancient Near East, which have 
led to contemporary divisions between the interests of academic Egyptologists and Egypt in pop culture. In this study, the burgeoning middle class and influential elite, with their access to leisure time and general romanticizing of antiquity, stand at the core of nineteenth-century interest in the Near East.

Befitting the theme of the first volume, Claiming and Conquering, McGeough carefully presents the problem of Orientalism and exoticism, including (following Frederick Bohrer) exoticism's creation of "our" paradoxical proximity to the distant "other" in the ancient Near East. The growth of archaeological studies in the nineteenth century, as he notes, "brings a physical proximity to the exotic by removing artifacts from an original geographic and temporal setting and resituating them in a new context of the museum or, more abstractly, the academic study" (I.I4). McGeough carefully builds upon this framework of archaeology as recontextualization: that the removal and replacement of ancient Near Eastern artifacts might reveal more about the culture involved in the objects' acquisitions than it does about the ancient culture itself. In preparation for the study, McGeough also notes in the introduction that travel literature was an inescapable medium of Near Eastern knowledge in the nineteenth century, due to its ability to display the "other" during the "heroic" European journey for transformative experience in exotic lands. McGeough, throughout this volume and subsequent ones, judiciously balances the realities of imperialism in Victorian-era Europe with the modern imperative to condemn such actions (via Edward Said and Rana Kabbani).

As one might expect for a study of nineteenth-century European interaction with the Near East, McGeough begins with Napoleon's invasion of Egypt and the rapid appropriation of Egyptian culture in France (ch. I) -at least, Egyptian culture as perceived by French artists and travelers. At the opening of this first chapter, McGeough notes an important feature of this Orientalizing treatment of the Near East that continues throughout the entire study: the objectification of Egyptian (and other Near Eastern) culture relies on fixing said culture in space and time, so that it can be easily examined and treated as timeless (I.36). McGeough makes clear that Napoleon and his "scientific team" established the standard for later Near Eastern travel literature and geographical studies of Egypt, primarily through the publication of Vivant Denon's Description de l'Egypte and Voyage dans la Basse et la Haute Egypt (I.32). With Denon's creation of the "nearly universal (and empirically based) 'ancient Egyptian' visual culture” (I.32), French elite quickly 
began to portray themselves as aesthetically and technologically competing with ancient Egypt - in many ways, Paris was portrayed as the heir to Egyptian monumental grandeur. As McGeough notes, Denon was also involved in the removal of Egyptian antiquities and their transfer to France, a quickly standardized practice that would plague museum ethics until the twenty-first century.

Outside of France's rapid appropriation of Egyptian aesthetic culture at the turn of the nineteenth century, McGeough also turns to the standard popular conception of the ancient Near East in Europe (ch. 2), which itself was primarily fueled by reading and interpretation of the Bible and other Greco-Roman texts. He presents the classical European image of Mesopotamia and Egypt as read through the literalized "Moses to Solomon" Old Testament narratives, Josephus, Herodotus, Manetho, Diodorus Siculus, and Plutarch. The discovery and deciphering of the Rosetta stone added to McGeough's discussion of European portrayals of ancient Near Eastern culture, as specialist Europeans were beginning to gain confidence in their ability to uncover and prove connections between the archaeology and geography of the Near East and their own classical/biblical conceptions of such locations.

McGeough's first volume continues with examinations of European travelogues of the Near East, especially those recorded by Giovanni Belzoni ( 7779 -I 824), Edward Robinson (I794-I863), and Austen Henry Layard (I 8 I $7-$ I 894). As noted in the previous chapter, many of these early European explorers desired to prove the literal nature of the Bible through the discovery of biblical towns (I.I09) - yet, this was primarily a Protestant project that avoided common Catholic pilgrimage sites and Jerusalem's thriving ecclesial traditions (I. I I 4). Perhaps most importantly, Layard discovered the biblical city of Nineveh during his travels and thereby founded the field of Assyriology in the I 840 s. As McGeough notes, this moment shifts the course of Near Eastern studies because "the political ramifications of Layard's books should be considered as this is one of the earliest loci where formal imperialist governance and archaeological practice are institutionalized" (I.r 29). The appropriation of Near Eastern archaeology for larger imperialist projects remains a major theme that goes far beyond McGeough's study of the nineteenth century to current excavations in the Middle East.

In tandem with imperialist projects, McGeough relates other Victorian impulses for understanding how previous empires have fallen in order to conceptualize further human "progress" and the potentiality of returning to a "Golden Age." He notes that the birth of ancient Near Eastern studies 
was often used as evidence that humans were not primordial savages, but rather were made by God to thrive in society (I.I43); this "discovery" arose contemporaneously with the development of positivist thought and Hegel's goal-oriented progression of history, the Weltgeist (I 44). Knowledge of the Near East in the nineteenth century leads to, as McGeough argues, the further subjection of African slaves as sub-human and the partition of human history into periods of savagery, barbarism, and civilization (cf. Spencer and Henry Morgan; Marx; Engels; John Stuart Mill). Even religion is seen as "evolving" in the developing Bibel-und-Babel discourses that emerged due to blatant similarities between biblical literature and Near Eastern mythological cycles. McGeough makes clear that appropriation and interpretation of the Near East in the nineteenth century reified contemporary modes of oppression, linear viewpoints of the progression of history and humanity, and religious justification for the supremacy of Christianity. These issues are quite relevant for contemporary European and American historical and religious discourses.

On a more popular level, McGeough treats Victorian periodicals, the beginnings of archaeological journals, and satire as interest in the Near East spreads throughout other European classes. As he understands it, these types of media functioned well for popular crowds due to their relatively cheap production and distribution prices, the ability to provide a visual experience, as well as the ability to read these media quickly (I.I 86). As one might expect from previous chapters, the general reader was expected to have a fair amount of biblical knowledge in order to interact with Near Eastern findings. McGeough also notes the continued emphasis on the linear progression of history, specifically in art history; interest in Assyrian and Egyptian art grew through these media due to the belief that they may have influenced Greco-Roman (and thereby later neoclassical) art forms (I.203). Especially after the fiasco surrounding the transportation, disappearance, and debates for "Cleopatra's Needle" in London, McGeough sees a surge in European satire focusing on the Near East, such as Mrs. Brown on Cleopatra's Needle, The Egyptian Red Book, and in the weekly magazine Punch. Common themes included the mocking of contemporary British sports, politics, and cultural values through the images of sphinxes, mummies, and the famous Nineveh bull (I.230-57). As authors such as William Thackeray of Punch made clear with their blatant satire, it had become difficult to distinguish between "traveler" and "tourist" during nineteenth-century expeditions to the Near East. As is a theme throughout McGeough's volumes, the ambiguity be- 
tween traveler and tourist places one in an equally ambiguous space between active participant and passive observer. How much is a traveler/tourist truly exploring, and how much is such a person shaping (or being shaped) by their Near Eastern surroundings?

Overall, volume one uncovers the monumental role of "non-specialists and non-professionals" in the development of nineteenth-century interest in the ancient Near East, as well as the subsequent professionalization of such endeavors by pseudo-academic travelers and state-sanctioned treks to Egypt (428). McGeough distinguishes the role of the professional and amateur by the end of this volume in order to lay foundations for the next two volumes, which survey amateur encounters with the Near East.

Volume two, with the subtitle Collecting, Constructing, and Curating, focuses primarily on the construction of the "Near East" within the contexts of museums, architecture, and art. This volume especially emphasizes the role of Egypt - or, at least, European conceptions of Egypt - in various forms of material culture. From the introduction, McGeough is clear that Western constructions are not true reconstructions of Near Eastern art and culture, but are utilized within new historical and political contexts:

Egypt is both full and empty as a signifier. That is to say, it seems to be evocative of so much but what it evokes is extremely flexible and subjective.... The "fact" of Egypt does not preclude the multiple "Egypts" that are imagined, exhibited, and manufactured, and despite the fact that this was a real, historical culture, its meanings for later interpreters are unstable. (II.3-4)

McGeough especially makes use of the methodologies and scholarship of "thing theory," a field of study that conceptualizes the appeal of "things" and "collections," particularly by what means people demonstrate wealth and selfhood through ownership of objects. McGeough questions whether a "thing" can transfer ownership intrinsically and instead follows Nicholas Thomas in suggesting that objects must be manipulated and placed in new contexts. This proposition is foundational for McGeough's study of nineteenth-century museums and their (re)presentations of the Near East, since, borrowing from Anthony Shelton, he suggests that "the museum institutionalizes and legitimizes a specific gaze. It teaches visitors how to view artifacts (and by extension the cultures that they stand for)" (II.7). For brevity, I will only highlight a few chapters from the second volume. 
In chapter I, McGeough again reminds his readers that twenty-firstcentury Near Eastern scholarship is the culmination of three centuries of professionalization within the field. Nineteenth-century archaeologists, collectors, and scholars did not hold the same standards or viewpoints concerning the study of history. "Artifacts could ... be examined in isolation or in relationship to other objects of the same type, but not within an archaeological context as had been the typical approach since the Enlightenment" (II.I I). McGeough notes that, as professionalization of the field emerges during the nineteenth century, ownership of artifacts shifted depending on the "uniqueness" of the object, so that the scholarly community gained control over more artifacts and Victorian museums became a "sacred space" for "sacred objects" (II.r9). McGeough's first chapter also wrestles with the burgeoning area of museum ethics, using the example of collector Sir John Soane and his questions concerning artifacts: should antiquities be owned by the government who discovered them, or by the discoverers themselves? What is the role of the country in which they are found? Most European collectors and travelers (e.g., Rifaud, Belzoni), as McGeough reveals, denied any claim of ownership to local governments or communities, often supposing that locals were xenophobic and overly possessive. McGeough helpfully uncovers the rhetoric of such collectors, as he notes that European and Ottoman authorities attempted to "stake claims" in foreign countries with almost total disregard for the role of local communities in ownership stakes. Finally, chapter I tackles the growing production of forged antiquities, especially after the discovery and display of the Moabite/Mesha Stele at the Louvre. McGeough's contribution to the definition of "authenticity" and "forgery" is helpful, since he expands upon Baudrillard's claims concerning the falsity of all artifacts (II.45). The Near Eastern artifact, in his expansion, is not "real" due to its role as an "object of fetish" in early modern European culture. Although the object is "false" due to its separation from its historical context, archaeological artifacts are given a new "realness" because of the relationship between object and owner. In McGeough's explanation of the Mesha Stele, he notes how copies-although equally as "fake" as the real Mesha Stele in some ways - are seen as intrinsically inferior by collectors and viewers due to the supposedly inferior relationship the owner/viewer might have with antiquity through the copy. McGeough's second chapter notes a similar desire for breaching the liminality between Europe and the ancient Near East through human remains (i.e., mummies; II. 57).

In chapter 3 , McGeough furthers the important discussion of museum 
ethics and institutionalized history, beginning with the observation that "to control a museum is to control a representation of a community and its highest values and truths" (II.I06). McGeough notes that, whether the nineteenth or twenty-first century, museum-goers usually fail to understand the mastery and control that comes about through the museum's depictions of Near Eastern artifacts. A major example used in this chapter includes Canning and Layard's excavation of Nimrud for the British Museum. McGeough notes the questions that arose in the nineteenth century concerning the efficacy of Near Eastern displays at the British Museum: how much do these displays positively benefit British culture? This interest in the formulation of culture and public identity through museums causes McGeough to focus on a hotly debated question for these types of museums: are they a location for displaying "gentlemanly status" or national identity (II. I 2 I-I 22)? Following Bourdieu and Habermas, McGeough argues that museums reveal who is elite and "in the know" within a culture, which is quite noticeable in the restricted attendance of the British Museum before I $8 \mathrm{I}$ o. McGeough argues further that the popularization and accessibility of museums in the nineteenth century prompted a method of control through museums. Working-class citizens could now interact with elite museum culture, but (following Foucault and Bourdieu), the museum became a medium of education on "proper" culture. The institutionalization of Eurocentrism and elite control of museum culture is a significant conclusion from McGeough's study of Near Eastern collections at the British Museum.

In the third and final volume, McGeough tackles two topics: "conscious fantasies" of Near Eastern culture in popular media (e.g., art, fiction, theater, music, opera) and non-academic or esoteric revivals of Near Eastern culture (e.g., Rosicrucians, The Hermetic Order, Mormons, Freemasons). In his introduction, McGeough furthers Said's discussion on orientalism by noting that "othering" simultaneously creates "selfing." In nineteenth-century biblical and Near Eastern art, this is evident in the blending of artificial images with lived experience, such that one's artistic imagination is limited to the imagined historical scene (III.4-6). Just as McGeough noted European and early American attempts to breach the temporal, geographical, and cultural differences between themselves and the ancient Near East in previous volumes (e.g., through mummies, archaeological artifacts, travel), he continues this discussion in the third volume through the development of esoteric approaches to the Near East. These religious and quasi-religious attempts to connect directly with the ancient world appear to be, as McGeough notes, "a 
response to the growing mechanistic view of the universe. For if there truly is no greater spiritual meaning to life, and religious traditions are just cultural constructs, why not just make up one's own? Or, one could pick and choose elements of various traditions and follow those that were most appealing" (III.ro). As is later claimed by Freud, the ancient Near East is utilized in modern European culture as a tool by which one may discuss taboo subjects.

For the sake of space, I will focus briefly on the first chapter of this volume and its implications for reception history of the Near East. McGeough begins this chapter with artistic depictions of biblical scenes by William Blake as one example of the nineteenth-century goal of veritas in art-as an attempt to "signal the real" (III.I7-I8). McGeough, however, is quick to note the modern European construction of progress and civilization through these media, which coincides with orientialist tendencies in artistic depictions of the "timeless East." Through the apocalyptic biblical scenes of John Martin, he reveals how the artistic destruction of Mesopotamia impacted later biblical and historical scholarship, which sought to (re)construct further accurate visuals of ancient cultures. Other artists of this period (e.g., Turner, Roberts, Delacroix), McGeough notes, are similarly interested in Near Eastern themes of destruction and hyperreal illustration of biblical scenes. As with the previous volumes, McGeough continually touches upon the orientializing of such artists, asking whether there is actually a distinction between the use of "ideal" illustrations for fantasy art and "real" illustrations for biblical art (III.43). McGeough also returns to his earlier discussion of the Near East and European taboo topics, since Victorian orientalist art depicts fantasies surrounding race, gender, and sexuality (e.g., Ernest Normand, Edwin Long, George Rochegrosse). He again argues that the imagined "distance" with the Near Eastern world made it an artistic space for exploration of unorthodox questions (III.75-80).

McGeough's meticulous three-volume study of Near Eastern appreciations and appropriations in nineteenth-century Europe should encourage students and scholars alike to consider the role of the Near East, both in the classroom and in contemporary society. McGeough urges his readers to recognize that we, just like many nineteenth-century Europeans, desire to connect with ancient people through their artifacts. Because of this desire, scholars ought to reexamine the nature of ownership and colonial consequences on the economies and cultures of modern inhabitants: "the past still exerts a powerful influence on the present, and, as in gothic literature, the sins of the father are visited upon the son" (III.389). Perhaps most im- 
portantly, McGeough argues for deeper recognition and further study of the intertwined nature of mass entertainment and professional archaeology. His three-volume series elucidates the relation between orientalizing travels, acquisition of Near Eastern artifacts, the creation of archaeology, and the growth in popular interest and esoteric interpretations of Near Eastern culture. From the multitude of relations between popular culture and Near Eastern studies starting in the nineteenth century, McGeough offers a challenge to scholars:

By trying to understand the needs that alternative histories fill for people, rather than just discounting this kind of pseudoscholarship outright, we can perhaps do a better job of exciting interest in our field without recourse to aliens, curses, or imagined mysticism. (III.390-9I)

McGeough thoughtfully urges scholarship to be more self-aware of the types of values that we encourage through our creation and contextualization of Near Eastern history. McGeough seeks innovative modes of Near Eastern scholarship that take seriously the desires of the non-professional and nonelite, so that scholars and students might further this field in an ethical and relevant direction.

Chance Bonar

Yale Divinity School

\section{The Bible, Mormon Scripture, and the Rhetoric of Allusivity, by Nicholas J. Frederick}

Madison and Teaneck: Fairleigh Dickinson University Press, 20 I 6 |xxxviii + I 5 I pages | ISBN: 978-I-6 I I 47-905-8 (hardcover) $£ 75.00$

Mark Twain, who actually seems to have read the book, humorously described the Book of Mormon as a "tedious plagiarism" of the Christian Bible. ${ }^{1}$ Most of the Book of Mormon's critical readers since then
Revdation given Thay, 183 saith the Lord, it shall come seth their sins and cometh us nd obeyeth my voice, and all see $m y$ fice, and know it THE BIBLE, MORMON

SCRIPTURE, AND THE RHETORIC OF ALLUSIVITY

NICHOLAS J. FREOERICK

a recenved of my rather, an lory; and the fuiness of Jol led: And he bore record, as in the beginning before the inning the Word was; for inger of salvation, the light

${ }^{1}$ Mark Twain, Roughing It, ed. Hamlin Hill (New York: Penguin Books, I98 I), I46. 
seem to have been inclined to agree, both that the volume is basically artless and that it is derivative. Occasional exceptions to this interpretive rule, however, have shown that the book deserves a closer look because, despite a certain aesthetic clumsiness, there is something genuinely sophisticated and compelling about the way the Book of Mormon handles the biblical texts it borrows. Thus in the late I970s, Krister Stendahl tracked in a preliminary study how the climactic sermons of Christ in the book impose a Johannine frame on certain Matthean texts (primarily the Sermon on the Mount). ${ }^{2}$ But not until the publication of Nicholas Frederick's The Bible, Mormon Scripture, and the Rhetoric of Allusivity has anyone developed in print a full study along the lines of Stendahl's relatively brief analysis. It is to be hoped that Frederick's book heralds a whole series of close investigations of how the Book of Mormon and other Mormon scripture interact with the Christian Bible.

Frederick's book assumes responsibility for demonstrating two things. First, he argues that Mormon scripture-texts presented to the world by Mormonism's founder, Joseph Smith—employs a "rhetoric of allusivity" that was meant, for its original nineteenth-century audience, to give it the weight of biblical authority. Second, he argues that this general reliance on biblical authority, accomplished through echoes and allusions, eventually launched Smith into a sustained critical interaction with biblical scripture, and specifically with the eighteen-verse prologue to the Gospel of John. In effect, what began for Smith as a source from which to borrow cultural and religious authority became eventually an interlocutor in an intensely speculative theological dialogue. Thus Frederick's study moves from chapters focused on mere echoes of and allusions to John's prologue in the earliest of Mormonism's scriptural texts to chapters focused on expansions and eventually inversions of the prologue as Smith's still-young prophetic career began to evolve.

What ultimately motivates the book is the existence of an I 833 revelation to Smith which presents itself as the Urtext (albeit in English) of John's prologue. It is a fascinating text, one that works out in preliminary form many of Mormonism's most theologically audacious claims, and it sets these forth through a direct and explicit engagement with the first part of the Gospel of John. Although Frederick never frames his study in these terms, the point of his investigation is arguably to ask how Smith made his way

${ }^{2}$ See Krister Stendahl, "The Sermon on the Mount and Third Nephi," in Reflections on Mormonism: Judaeo-Christian Parallels, ed. Truman G. Madsen (Provo, UT: BYU Religious Studies Center, 1978), I39-54. 
from relatively conservative interactions with Johannine texts in the Book of Mormon-where interaction is largely limited to authority-borrowing echoes and allusions - to more heterodox interaction and outright contestation of the Johannine text. That this development happened between I 829 (during the summer of which Smith dictated the entirety of the text of the Book of Mormon) and 1833 (late in the spring of which Smith produced the revelation that recasts the origins of John's prologue) is quite remarkable. In four years, Smith apparently shifted from regarding the biblical text as largely authoritative as it stands to malleable and open to contestation and radical reinterpretation.

Every stage in the story Frederick tells is compelling. In his first chapter, focused primarily on the Book of Mormon, but also on a relatively early (I 83 I) revelation to Smith, he tracks the use of relatively vague echoes of John's prologue. Cutting across traditional debates about what such echoes mean about the Book of Mormon's claims regarding its historical provenance, he emphasizes the ways the text deliberately addresses itself to a nineteenthcentury audience and presents itself in the garb of quasi-Johannine language in order to command a certain position of authority with a still-thoroughlyChristian readership. He finds the same rhetorical gesture in Smith's earliest revelations. Then, in a second chapter, Frederick looks at more obviously deliberate allusions to John's prologue, places where the earliest of Mormon scriptural texts borrow not only the language but also the basic contextual meaning of Johannine texts. Here again Frederick focuses just on the Book of Mormon and on the earliest of Smith's revelations (from I 828, i 830, and I $83 \mathrm{I}$ ). And as with vaguer echoes of John, more obviously deliberate allusions to John are, he argues, "rhetorical rather than theological" (I 5 ). They serve to underscore the close relationship between new and ancient scripture, such that the former can borrow the authority and cultural force of the latter.

The story grows more complex in Frederick's third chapter. There he traces moments already in Smith's earliest scriptural texts where there are "significant new dimensions" added to the Gospel of John's prologue (57). The earliest of these, though, are relatively humble developments of Johannine texts. But then, beginning with a recorded vision experienced by Smith and a companion in February I 832, the first relatively drastic developments of John's prologue start to appear, initially by a refocusing of the Johannine theme of fullness, shifting it away from the logos of John's prologue to outline a theology of "the fullness of the Father" (79). Frederick follows Richard Bushman in calling this the first of a series of "exaltation revelations" 
(77). It is the well-known vision canonized as Section 76 of the Doctrine and Covenants, the scriptural collection of Smith's revelations. In another revelation from December 1832, Frederick finds further theological developments of the Johannine notion of fullness, as well as a remarkable reconceptualization of the Johannine prologue's talk of light as material and cosmic rather than merely metaphorical. Further, according to Frederick, Smith reworks John's well-known idea that many witnesses were necessary for Christian faith, to "reduce the importance of these witnesses" because "all one needed to do was look around and, in an Emersonian fashion, recognize the divine" (85). In these developments, one recognizes the beginnings of a theologically audacious handling of the biblical text.

Only in Frederick's fourth and final chapter does this story reach its climax. In the already-mentioned I 833 revelation, Smith produces the supposed original from which the Gospel of John's prologue was eventually derived. The production of this text amounts, according to Frederick, to one of Smith's "deepest engagements with any text of the Bible and results in what is arguably his greatest theological construction" (96). Frederick analyzes in startling detail the close but complex relationship between Smith's text and the biblical prologue of John. He shows that Smith's production borrows "the spirit and intent of the Prologue" (99) by reproducing its basically supersessionist gesture (albeit in order to allow Mormonism to supersede Christianity, rather than to confirm Christianity's supposed supersession of Judaism). The deconstruction and then reconstruction of John's prologue in Smith's revelation further replaces the Johannine high Christology (clearly embraced in the Book of Mormon) with an emphatically low Christology (central to much of subsequent Mormon theology) — a low Christology that, moreover, makes of Christ an example of progression "from grace to grace" toward the Father's fullness ( I I o). What reveals early Mormonism's remarkable interaction with the Christian Bible is the fact that Smith presents this not as a straightforward rejection of John's prologue in favor of an alternative theology, but as a restoration of the prologue to its supposedly original form. This Smith accomplishes by retaining much of John's language, skillfully tracking points of tension and possibility in the biblical text, and then manipulating the text to bring out its latent potential meanings.

In the end, what Frederick makes perfectly clear with this study is that early Mormonism deserves closer study for its inventive interaction with the Christian Bible. Far from providing tedious plagiarisms, Mormon scripture provides a sophisticated and theologically interesting engagement with the 
material text of the Bible. Not only might much be learned about Mormonism from closer study of its scriptures with biblical texts, but also much might be learned about the tensions and potentialities of the biblical texts themselves. Frederick has provided a remarkably strong example of methodological care in this book. The book serves to outline a methodology for tracking biblical interactions in texts clearly dependent on the Christian Bible but introduced to the world only long after the closure of the biblical canonMormon or otherwise. The book unquestionably succeeds in what it presents as its chief aim, even though this is arguably not really its chief aim or its most important contribution. It might be noted that Frederick has elsewhere published a sustained study of methodology for considering biblical interaction in the Book of Mormon (see Nicholas J. Frederick, "Evaluating the Interaction between the New Testament and the Book of Mormon: A Proposed Methodology," Journal of Book of Mormon Studies 24 [2015]: I-30).

At the same time, however, Frederick's study is not without its flaws. Chief among them, from my point of view, is its overt insistence on being primarily a study in methodology. In the book's introductory material, Frederick presents his work as an attempt at refining the methods used to find and categorize interactions in non- and pseudo-biblical literature with biblical texts. He defends the limitation of his attention to Mormon scripture's use of John's prologue, for instance, not by pointing out that it receives especially illustrative attention in an I 833 revelation, but simply on the grounds that it is a peculiarly unique and theologically robust part of the Christian Bible (see pp. $\mathrm{xx}-\mathrm{xxi}$ ) and so might be useful in a methodological study. This ultimately obscures the teleological flow of Frederick's study and distracts attention from the fact that there lurks, in the course of the book, a remarkably strong thesis about Joseph Smith's peculiar interest in the Fourth Gospel. Strengthening this misdirection of sorts, Frederick neglects in the book to engage as directly as he might with the explicit interest Mormon scriptural texts exhibit in specifically Johannine texts. Frederick seems to me to have missed an opportunity to make a direct and forceful case that there is a kind of systematic (if nonetheless changing) program of interpretation of Johannine texts in Mormon scripture. Although he does cite Stendahl's study of the Johanninization of Matthean texts in the Book of Mormon, he never engages in any sustained way with Stendahl's conclusions. Further, as noted, he avoids addressing, even in synoptic fashion, important explicit statements regarding the Johannine corpus in Mormon scripture-the direct survey of correct and misguided interpretations of John I 0: I 6 in the Book of Mormon, 
for example, or repeated references to John and the Apocalypse throughout the Book of Mormon. Frederick's book would have been strengthened by at least some direct discussion of these overt interactions with John, at least by way of contextualizing the more subtle use of John's prologue at strategic points in Mormon scripture.

This, though, should be heard as a mild critique-a suggestion that Frederick might profitably be less modest about what he attempts to track in Mormon scripture. A stronger thesis, which I believe is supported by Frederick's findings, would more forcibly reveal how closer study of Mormon scripture would reward those who give it attention. Yet Frederick has nonetheless done much to reveal just this. For that he is unquestionably to be commended.

\author{
Joseph M. Spencer \\ Brigham Young University
}

\title{
The Gospel According to the Novelist: Religious Scripture and Contemporary Fiction, by Mag- dalena Mączyńska
}

New Directions in Religion and Literature | London: Bloomsbury, 20I5 | I 52 pages | ISBN: 978-I-350-02844-9 (hardcover) \$94.00 | ISBN: 978-I-780-93623-9 (softcover) \$39.95

Magdalena Mączyńska’s study of modern literary rewritings of the gospels is an astonishingly compre-

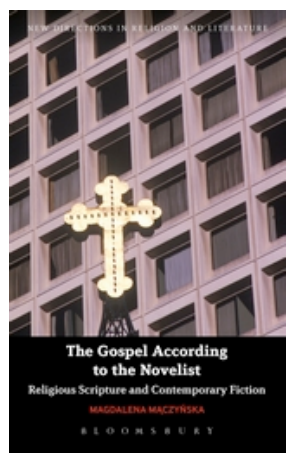
hensive survey for a book whose main text runs to only I Io pages, or 144 including the notes. She manages to discuss most of the significant hypertexts from Robert Graves's King Jesus (1946) to Naomi Alderman's The Liar's Gospel (2012), as well as some precursors. (The only major omission I noted was Vincento Leñero's The Gospel of Lucas Gavilán [1979], a remarkable Marxist modern-dress reiteration of the gospel story, transferred to I 970 Mexico, which is as critical of institutional Christianity and as comical as any of the novels which are explored here.)

The author begins by defining her interest as lying not in religion as a literary theme nor in narratives which set out to revitalize the canonical stories by supplying historical reconstructions or transferring the plots to a modern setting. Rather her concern is with novels that are scriptural rewritings which 
explore the boundary between religious and literary discourses. She selects the term scriptural metafiction (drawing on Linda Hutcheon's account of historiographic metafiction) to describe works which deconstruct scriptural material and at the same time provide their own versions of gospel events. The origins of the modern trajectory are traced back to Strauss's Das Leben Jesu and Renan's La Vie de Jésus as writers make more and more explicit the manmade character of the original gospels. Successive sections explore the atheist hermeneutics of suspicion evidenced in José Saramago's The Gospel According to Jesus Christ and Philip Pullman's The Good Man Jesus and the Scoundrel Christ; the alternative (feminist) viewpoint provided by such gospel rewritings as Michèle Roberts's The Wild Girl and Colm Tóibín's The Testament of Mary; the "hidden years" gospel material supplied by a range of works from Nicolas Notovitch's La vie inconnue de Jésus to Christopher Moore's Lamb: The Gospel According to Biff; the postmodern or postsecular rewritings which emphasize the multiplicity of possible perspectives (for example Nino Ricci's Testament); and finally more carnivalesque reworkings exploiting the science fiction genre of time travel, such as Michael Moorcock's Behold the Man and Gore Vidal's Live from Golgotha. In the case of Vidal's reworking, the resultant narrative serves to illustrate Baudrillard's argument that "the simulacrum obscures not an underlying reality, but rather its absence." Chapter 4 reviews the inscription of sensational scholarly textual and archaeological research in a range of works, culminating in Michael Faber's Fire Gospel and taking in (inevitably) the impact of Dan Brown's The Da Vinci Code. One of the most interesting sections examines Gabriel Meyer's The Gospel of Joseph. With its multi-layered combination of fictive documentary archive and a plot line involving a scholar commissioned by the former DDR to deliver a propaganda coup demolishing Christianity, it offers an exposition of the fluctuations in the meanings and values of sacred texts and the opportunities for political and ideological manipulation.

Inevitably there are critical lacunae. There are no bibliographical references for the mentioned study by Robert Cousland dealing with Saramago's novel The Gospel According to Jesus Christ (3 I-32). Despite devoting much space proportionately to novels dealing with Judas Iscariot, there is no mention of either of the two main scholarly surveys of the subject, Kim Paffenroth's Judas, Images of the Lost Disciple (200I) or Susan Gubar's Judas: A Biography (2009). In the section covering Naomi Alderman's The Liar's Gospel, the novelist's stress on the power of the storyteller to manipulate her subject and to tell lies is not balanced by any mention of the evidence from 
two centuries of folkloric studies on the faithfulness of oral transmission in its preservation of tradition. In the study as a whole, there needs to be more recognition of the fact that every rewriting, including Vidal's lampoon, depends on the stability of an at least notional hypotext, even if that hypotext is (in the case of the canonical gospels) pluritextual. This might have provided a fruitful extension to the author's very useful short account of the history of gospel harmonies.

Mączyńska's Conclusion (107-10) is a little brief, especially as it starts with an excursion into yet another field, that of the pious expansion found in the phenomenally successful Left Behind series and The Jesus Chronicles, albeit as a foil to the other material surveyed in the book. Upholding the value of scriptural metafiction as a way of exposing the abuses engendered by modern capitalism and forms of patriarchal oppression, but above all as a way of resisting the "fetishization of canonical biblical texts," the study hints at a horizon in which the hermeneutical skepticism on display in the works discussed has "far-reaching philosophical and political implications." Presumably that demands another volume. For now, though, we have an indispensable resumé of the territory occupied by radical fictional rewritings of gospel material.

\author{
Anthony C. Swindell \\ Area Editor (Literature), EBR
}

\title{
The People's Book: The Reformation and the Bible, edited by Jennifer Powell McNutt and David Lauber
}

Wheaton Theology Conference Series | IVP Academic: Downers Grove, 20I7 | 250 pages | ISBN: 978-0-8308-5163-8 (softcover) $\$ 25.00$

"Of the making of Reformation Anniversary celebration observation books there is no end" may be a line

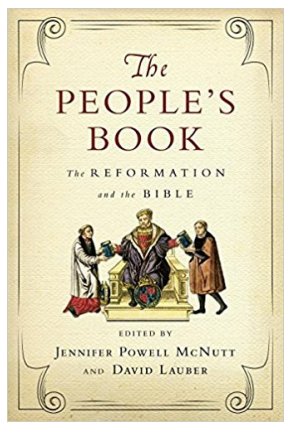
that Qoheleth would proffer were he alive today. The market has been flooded with volumes focusing on Reformation themes since scholars remembered the 5ooth Anniversary of Martin Luther's reformatory efforts would fall in 20I7. The present volume is one of them. 
In The People's Book: The Reformation and the Bible, McNutt and Lauber collect a series of essays which were originally delivered at the 2016 Wheaton Theology Conference and offer them to a wider audience than that which first heard them orally. Both the venue and the publisher are clues to readers as to the contents of the book since Wheaton is a conservative Christian institution and IVP Academic is a conservative Christian publisher. Accordingly, we already know that the book in hand will be a work of conservative Christian scholarship.

That fact is neither a word of praise nor a statement of condemnation. Instead, it is a cue to the reader that the tome will not be breaking new ground but rather it will assemble in a readable form the status questionis. Preconceptions will be confirmed and buttressed and both the Bible and the Reformers who handled it and taught it will be honored in due measure.

The work is made up of twelve chapters in four parts:

Part One: Access and Readership. I) "Teaching the Church: Protestant Latin Bibles and their Readers," Bruce Gordon; 2) "Scripture, the Priesthood of All Believers, and Applications of I Corinthians I 4," G. Sujin Pak; 3) "Learning to Read Scripture for Ourselves: The Guidance of Erasmus, Luther, and Calvin," Randall Zachman; 4) "The Reformation and Vernacular Culture: Wales as a Case Study,” D. Densil Morgan.

Part Two: Transmission and Worship. 5) "The Reformation as Media Event," Read Mercer Schuhardt; 6) "The Interplay of Catechesis and Liturgy in The Sixteenth Century: Examples from the Lutheran and Reformed Traditions," John D. Witvliet; 7) “Word and Sacrament: The Gordian Knot of Reformation Worship," Jennifer Powell McNutt.

Part Three: Protestant-Catholic Dialogue. 8) "John Calvin's Commentary on the Council of Trent," Michael Horton; 9) "The Bible and the Italian Reformation," Christopher Castaldo; ro) "Reading the Reformation after Newman," Carl Trueman.

Part Four: The People's Book Yesterday and Today. I I) "From the Spirit to the Sovereign to Sapiential Reason: A Brief History of Sola Scriptura," Paul C.H. Lim; I2) "Perspicuity and the People's Book," Mark Labberton.

The volume also includes acknowledgements, an introduction, a list of contributors, an author index, a subject index, and a scripture index. The present review, I must hasten to say, is based on a pre-publication copy in soft cover which is absent the final edition's paginations and indices. Consequently, I will not be able to provide page numbers for the extracts I cite, for which I apologize. 
Our editors describe their vision for the volume in the introduction, writing,

This volume examines many facets of the Bible as the people's book during the Reformation by reflecting on matters pertaining to access, readership, media, culture, diffusion, and authority as well as its place in the worship context, as the arbiter of theological interpretation, and as a contributor to unity and division within Christianity.

Immediately following this summary they briefly describe the contents and purposes of the various enclosed essays. Each essay has its own special merit but in the view of the present reviewer that by Bruce Gordon is extraordinarily meritorious. As he suggests,

My purpose ... is to broaden our understanding of Protestant biblical culture in the sixteenth century by posing a series of questions that will lead to the heart of what the Reformers sought in restoring the Word to the church.

He succeeds, masterfully. There is not a single paragraph in the essay which does not effuse learning and deep familiarity with the primary sources and the secondary literature. Erasmus, Jerome, Luther, Zwingli, Calvin and even Münster all make appearances and the story of the Latin Bible, which few would associate with the Reformation at all, has its story told vividly and intelligently.

Much of what appears in Gordon's essay in terms of his discussion of Zwingli and Zurich and the Latin Bible can be supplemented by interested readers who consult the same author's essay in the 20I 4 edition of Zwingliana, pp. I-33, titled "Remembering Jerome and Forgetting Zwingli: The Zurich Latin Bible of I 543 and the Establishment of Heinrich Bullinger's Church" (see n. 28 in Gordon's essay for this and further citations).

Gordon remarks a bit further on:

The Latin Bibles produced by the Protestants in the Sixteenth Century provide a narrative for the Reformation itself. They were a revolutionary creation in which the Hebrew and Greek texts formed the basis for the Bible that shaped the churches of the Reformation. 
And he concludes with this utterly fantastic quote from Konrad Pellikan, the greatest Hebraist after Johann Reuchlin of the sixteenth century: "With the vernacular Bible we teach the people. With the Latin we defend the Church."

Gordon's essay is placed, I assert, at the beginning of the volume because it is the best of the volume. But others are exceptionally noteworthy as well. "The Reformation as Media Event" by Schuchardt is also extraordinary. Here too learning is on full display. For instance, did you know that "... Gutenberg Bibles were not the first items to be printed? The first items to be printed were in fact medieval Catholic indulgences." And that

[t] oday's Catholics cannot acquire a printed letter of indulgence; instead, they receive indulgences that are verbal, acoustic, and spiritual in that the indulgence is itself an invisible thing that one "receives" in exchange for some act or service. Pope Benedict offered indulgences for downloading the Catholic app. Pope Francis granted indulgences to Catholic faithful who follow his Twitter feed in $2013 \ldots$.

What readers have, then, in this book, is a series of essays which open windows on the history of the Reformation which when opened shed more light than previously available.

Yet not all is well. The essay by Horton on Calvin's commentary on Trent is regrettable for its shortsightedness. That is, at the conclusion of his contribution Horton opines, "Yet as this examination of the Antidote reveals, for Calvin the central issue is solo Christo-Christ alone 'as he is clothed in the Gospel."” As experts in Calvin and his thought will immediately recognize, it is simply impossible to boil Calvin down to a "central issue." Calvin's theology is far too broad for such narrow-fying strictures. To say that Calvin was operating from the basis of a "central issue" is the same as saying that the Bible has "one concern." That too is a flattening. Calvin had his eyes on many things all at once. Horton has poked out most of those concerns in order to form a Calvin in his own mind who fits his own ideology. But Calvin is too big for that. Calvin cannot be made in the image of Horton. He cannot even be recognized in that image.

But rather than end the present review with a negative, allow me to return to the positives of the volume. And one of them is the final essay, that by Labberton, on the perspicuity of the Bible. After cleverly noting that the 
perspicuity of the Bible is hardly perspicuous he goes on to make the salient observation that

the priesthood of all believers did not mean the equality of all readers.... Luther and Calvin could only imagine Bible reading occurring in the context of Christian community and not by isolated readers on their iPhones between dumbbell sets at a twenty-four hour fitness club.

True words, contained in a volume filled to the brim with truthful examination (for the most part - the essay by Horton being the singular exception) of the Reformation's use and view of the Bible. The Bible truly is the people's book-so long as and insofar as those people are members of the community of faith-the Church.

Consequently, I conclude by assuming the heavenly voice heard by Augustine in the garden as his Bible fell open to Romans and urge readers of this review to "Tolle, lege!" the book by McNutt and Lauber.

Jim West

Ming Hua Theological College

\section{A New Gospel for Women: Katharine Bushnell and the Challenge of Christian Feminism, by Kristin Kobes Du Mez}

Oxford: Oxford University Press, $2015 \mid x v+264$ pages $\mid$ ISBN: 978-0-190-20564-5 (hardcover) £20.49

In today's religious marketplace, Christianity and feminism seem to be close allies in academic circles. With books like Jesus Feminist, Rescuing Jesus, and Jesus Was

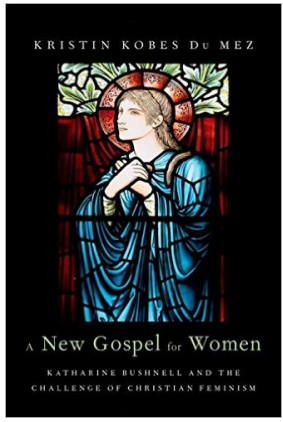
a Feminist, as well as numerous feminist biblical commentaries, journals, and societies, it is sometimes hard to picture a time without the two standing side by side in one way or another. Yet Kristin Kobes Du Mez's A New Gospel for Women takes readers back to a time when it was possible that the two could be irreconcilable, if not in complete contradiction to one another. Given that feminism was the radical movement set to turn traditional gender norms upside down, and Christianity was the ancient patriarchal establishment set on 
maintaining male dominance, it is not difficult to see why these two would have had an uneasy relationship. In studying this relationship, Du Mez tells the story of Katharine Bushnell (I855-1946), a Holiness Methodist missionary doctor who spent a lifetime challenging the status of women within Victorian Christianity and wider society, and also reinterpreting the role of women within the Bible. In short, Bushnell sought to provide feminism with Christian spirituality, and Christianity with gender equality.

Bushnell was born in I 855, in Peru, Illinois, and later attended Northwestern University followed by the Chicago Women's Medical College, specializing in nerve disorders. Soon after graduating from medical school she arrived in China to serve as a Methodist missionary. Despite establishing a pediatric hospital in Shanghai, Bushnell viewed her time spent as a missionary as a failure. Yet her time living in China proved to be a turning point in her life, particularly after studying a Chinese translation of the Bible. Bushnell noted that the apostle Paul's female co-workers mentioned in Phil 4:2-3, Euodia and Syntyche, had been turned into men. Looking at English translations of the Bible, she saw similar sexist translations and interpretations. Upon returning to the United States, Bushnell began working on a Bible designed for women. Drawing on her knowledge of ancient languages and personal study, in 1908, Bushnell published her most famous work, God's Word to Women: One Hundred Bible Studies on Women's Place in the Divine Economy.

Du Mez's A New Gospel for Women weaves Bushnell's biography, thought, and theology to provide a historical study of an overlooked and undervalued figure within feminist and American religious history, and also to provide a challenge to modern readers to consider "what shape ... freedom might take for the twenty-first century." Du Mez's construction of Bushnell is complex and fascinating, compelling and engaging. After learning about her efforts to expose forced prostitution in Wisconsin lumber camps, then in India where the British government had established brothels to service soldiers, it is hard not to be inspired by her passion for sexual and social justice.

Some of her ideas about biblical stories make for fascinating reading. For example, her understanding of the Fall in the Garden places the main burden of sin onto Adam, not Eve. According to Bushnell, only Adam is expelled from the Garden of Eden, and it is Eve's choice to follow him that leads to her fall. Yet her opposition to contraception, abortion, and homosexuality as sin and "crimes against reproduction" clearly isolates her from modern feminist thought. Due to her radical readings of the Bible, Bushnell fell out of favor 
with conservative Christian groups, but because of her conservative values, she was not liberal enough for the new form of sex-positive feminism that was emerging.

For historians, particularly those of biblical reception and interpretation, one of the most helpful elements of Du Mez's work is how well she situates Bushnell within nineteenth-century American Bible culture. Because the late nineteenth century gave birth to a range of new Bible translations and commentaries, Bushnell's role in pointing out the sexism of older translations, her study of Greek and Hebrew, and her own biblical commentary make for fascinating reflection. As Du Mez points out, while much of Bushnell's thought was quite radical, she remained committed to conservative theology, thus producing a bitter opposition to Darwinism and Higher Criticism. It is this seeming contradiction that makes Bushnell so complex. Despite what can be seen as a fundamentalist allegiance to the authority of Scripture, her exegesis promoted the emancipation of women and radical change within church and society. With these juxtapositions in mind, Du Mez highlights the ways our ideas about liberalism and conservativism, fundamentalism and modernism, fail to understand figures like Bushnell in all their complexity.

Du Mez makes a compelling case to rethink the way conservative Christian women are viewed within many mainline Protestant churches. Rather than being a product of patriarchal norms, they might be partaking in a different form of Christian feminism, one pioneered by and rooted in the work of Bushnell. Additionally, by using Bushnell as a model, Du Mez challenges these conservative churches to think outside traditional hermeneutics in the pursuit of gender equality and liberation for women. Perhaps the best reminder for this is the reception of Bushnell's God's Word for Women, which was praised by the Moody Bible Institute, The Baptist, The Christian, and other conservative voices. Du Muz's work should give us pause about how people like Bushnell do not easily fit into our preconceived notions and categories of "liberal" and "conservative."

According to Du Mez, Bushnell and figures like her provide an alternative to rigid forms of "secular feminism" and "family values" evangelicalism. This, however, might be granting Bushnell too much. Given the heated debates over women's leadership, contraception, and same-sex marriage, it is difficult to imagine how Bushnell's theological positions would stand in churches like the Episcopal Church, United Church, and Disciples of Christ. It is more likely that Bushnell would still have a wider reception among conservative Christians, promoting the "different but equal" approach to gender within 
church and society. Yet one might hope that studying a figure like Bushnell might stir more dialogue between Christian and secular feminists. Regardless of their differences, their shared history is important and Bushell's role in the struggle for gender equality within nineteenth-century America should not be forgotten.

With the surge of interest in gender politics and feminism, Du Mez's $A$ New Gospel for Women is a welcome and unique contribution about a woman who deserves more attention. Du Mez provides a powerful challenge for people to reconsider the history and relationship between conservative forms of Christianity and modern American feminism. A New Gospel for Women is both a thought-provoking work of history and a necessary read for anyone interested in the reception of feminism and biblical reception.

\section{Daniel N. Gullotta \\ Yale Divinity School}

\section{The Bad Jesus: The Ethics of New Testament Ethics, by Hector Avalos}

Bible in the Modern World 68 | Sheffield: Sheffield Phoenix Press, 20I5 | xiv + 46I pages | ISBN: 978-I-909697-737 (hardcover) $£ 60.00$ | ISBN: 978-I-909697-79-9 (softcover) $£ 25.00$

This provocative and controversial book by Hector Avalos is a sequel to his previous book Slavery, Abo-

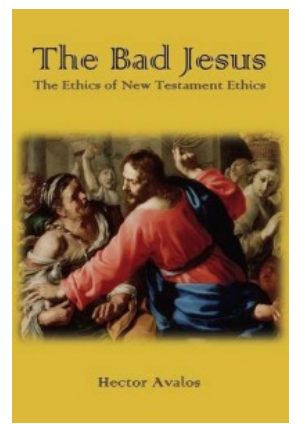
litionism, and the Ethics of Biblical Scholarship (see Peter Lineham's review in Relegere 4, no. 2 (20I4): 289-93), wherein he continues his meta-critical agenda of debunking the Christian orientation of modern biblical scholarship. In fact, its main title The Bad Jesus announces the big picture of what the author is attempting to achieve. According to the author, "bad Jesus" means that many of the ethical principles proclaimed or practiced by Jesus are antithetical to the most widely accepted founding principles of contemporary ethics, namely, the United Nations' Universal Declaration of Human Rights (UDHR). The subtitle The Ethics of New Testament Ethics, however, reveals the author's more fundamental concerns. Behind all the detailed discussions about the ethics of Jesus lies the author's meta-ethical question as to 
whether it is ethical to rely on a text or a revered figure, ancient or modern, to formulate ethics.

The origin of this book lies in the author's bafflement in reading academic literature on Christian ethics, where Jesus allegedly never does anything wrong. Hector Avalos, a self-declared New Atheist and professor of Religious Studies in Iowa State University, rejects "scholarly" attempts to idolize Jesus or render him a paradigm of modern ethics. According to the author, Jesus is a man who holds pre-scientific and imperialistic worldviews prevalent among first-century Palestinian Jews and consequently his ethical principles are flawed by modern standards. Why then do biblical scholars always portray Jesus in a positive light? Avalos answers this question essentially in two steps. First, biblical scholars' high Christology is to blame. For them, since Jesus is God, he can't be wrong. Second, even those who do not subscribe to this theological presupposition are still part of what the author calls "an ecclesial-academic complex" (280) and hence the New Testament ethicists do not give up their academic pretensions when it comes to defending Jesus as always being ethically right. Indeed, many of them do engage in historicalcritical and descriptive studies of the Gospels, but their scholarship seems to serve as an apologetic tool for their religionist agenda. To this end, the author claims to include a series of case studies in this book that are meant "to illustrate the extent to which religionism and more particularly a Christian bias still permeates what are otherwise supposed to be historical-critical descriptive studies of the ethics of Jesus" (27).

Each case study follows the same pattern of logic: Instead of proving his hypothesis for the bad Jesus, Avalos tries to disprove its opposite, namely, the good Jesus advocated by New Testament ethicists. The author's exegetical discussions, which is the meat of the book, focus on refuting positive portrayals of Jesus presented by New Testament ethicists and uncovering the religionist agenda of their academic endeavor. Avalos also brings in extra-biblical materials relevant to the issue in question in order to demonstrate either that Jesus's good ethical principle is not innovative or that his purported good principle is not good at all, when placed in its proper historical context. By so doing, Avalos wants to disabuse the readers of the idea that non-Christian oriental cultures are not ethically innovative or not as humane as Christianity. The book ends with an appendix meant to show New Testament ethicists' ignorance of non-Christian literatures, an extensive bibliography, and two indices of references and authors.

To be more specific, chapters 2 through 6 deal with ethical qualities of 
human interrelations such as love, hate, violence, and social hierarchies. In chapters 2 and 3, in particular, the author argues that the love Jesus advocates is neither selfless nor inclusive, but may entail hateful violence, when properly understood in the context of an ancient vassal treaty. Love in that context is equivalent to obeying the superior's directives, irrespective of what they entail. Chapters 4 and 5 address the issue of violence. While Christian pacifists portray Jesus as being non-violent, the author shows that Jesus takes full advantage of violence for his imperialistic agenda. Even those passages where Jesus seems to oppose violence should be understood as "deferred violence" (violence meant to be performed at a future time: cf. Matt 25:4I-46) in mind. "Non-violence should refer to the repudiation of violence in any form and under any circumstances," the author adds (IOI). In chapter 6, which addresses social hierarchies, Avalos claims that just because Jesus is opposed to the Roman empire does not make him an egalitarian or an antiimperialist, instead, Jesus simply replaces the Roman empire with another empire called the Kingdom of God. He maintains a hierarchy among his disciples, not to mention his exculpatory attitude toward slavery.

Chapters 7 through io address Jesus's attitude toward specific groups of people: namely, Jews, the poor, women, and the disabled and Avalos calls Jesus anti-Jewish, anti-poor, misogynistic, and anti-disabled. He goes so far as to compare Jesus's anti-Jewish rhetoric to that of Adolf Hitler and Jesus's dealings with the poor (impoverishing their families by demanding the disciples abandon their families, while receiving the labor of his disciples in return for nothing but heavenly rewards) to those of Harold Camping, the American Fundamentalist Christian, who impoverished his followers with false prophecies about the doomsday. Chapters I I-I 3 treat Jesus in relationship to broader phenomena and institutions. In chapter I I, Avalos addresses Jesus's faith healing and practically identifies Jesus as a magician who assumes supernatural etymologies and cures when it comes to illnesses, and calls him "a bad Jesus by modern medical standards." In chapter I 2 , which addresses Jesus's environment ethics, the author in essence argues that Jesus is anthropocentric and utilitarian in his attitude to nature. Finally, in chapter I3, Avalos compares Jesus's use of the Old Testament unfavorably to that of Mel Gibson in the film The Passion of the Christ. He criticizes New Testament ethicists of applying double standards: when Gibson gets his facts wrong or blatantly misrepresents scripture, they call it irresponsible and dangerous use of scripture, whereas they view similar misuses of scripture by Jesus as a normal part of his cultural context. 
Whether or not one agrees with the author's conclusions, this book is the first systematic challenge to New Testament ethics by an atheist scholar firmly grounded in the Hebrew Bible and its ancient Near Eastern context and well-versed in New Testament and Early Christianity. The arguments that Avalos marshals in refuting the New Testament ethicists are certainly worth considering. Even his overall conclusion is not as shocking as it may sound at first. He simply argues that some of what Jesus said and did appear comfortably placed in the ist century Palestinian culture, but are contrary to the modern ethical sentiments enshrined in the UDHR. And he accuses the New Testament ethicists of attempting to make Jesus anachronistically modern. The following reflections are more concerned with meta-critical issues than with details of his exposition of scripture.

First, it is one thing to say that Jesus is not modern in his ethics, and quite another thing to say that Jesus is unethical or "bad." I also disagree with the author's assertion that it is unethical to rely on any text or any person, ancient or modern, to formulate ethics. Avalos should know that we do not formulate ethics ex nibilo. Our practical reason rests on certain a priori foundations. These include not only scientific facts but also what I would call "tradition"-namely, accumulated communal reflections on what it is to live as a human being under various circumstances-which has been transmitted to us in canonical literature. The UDHR is itself a product of practical reason interacting with scientific facts and various political-ethical traditions. Indeed, the Bible is one of those traditions. The ethics uprooted from or formulated independent of tradition is in danger of being utopian in its perspective. We need ethical principles that can empower an individual (living in less than ideal societies as most of us do) to lay the foundations for a more just and better society in the midst of a sea of injustice. The Bible helps us to understand the fallen condition of the world and helps us formulate ethical principles to enable us to do just that. The reason why Avalos considers it unethical to rely on the Bible or Jesus may relate to his a priori acceptance of modern science and democracy as the Greatest Good.

Second, the mere disproving of the portrayal of Jesus presented by New Testament ethicists does not make the author's portrayal of Jesus necessarily right. As he admits, it is extremely difficult to reconstruct the historical Jesus, so it is best to work with the Jesus of the Gospels. Then the issue becomes hermeneutical. Avalos is not entitled to call the opponents' position "unscientific" or "apologetic," because of their theistic presupposition, because his exegesis is also influenced by his own atheist presupposition. He also uses 
his scholarship as a tool to promote his own agenda. This may account for the "strange" fact that Avalos attacks New Testament ethicists as any fundamentalist would. To quote Lineham, "The result is wild exaggeration based on a very literal reading of the text." For instance, Avalos staunchly rejects other interpretive possibilities for the phrase "to hate one's father and mother and wife and children and brother and sister" in Luke I 4:26 and speculates that Jesus literally preached hatred among his disciples for his imperialistic agenda.

Third, the observation that Jesus never does anything wrong in academic literature of Christian ethics does not necessitate the conclusion that New Testament scholars are religionist. The consistently positive portrayals of Jesus by these scholars may be due to the generic nature of the Gospels. The Gospels are generically similar to Greco-Roman biography (bios), whose purpose is encomiastic, instead of being critical. The Gospel writers may have intended no negatives for Jesus in the first place, although the Jesus of the Gospels may appear to violate modern standards of ethics. If this is the case, it is only natural that biblical scholars who seek authorial meanings should consistently arrive at positive portrayals of Jesus.

These observations do not detract from the fact that Hector Avalos has rendered a great service to the academic community by writing this stimulating, informative, and yet undeniably controversial book and it deserves a close reading whether or not one agrees with the author's conclusion.

Koowon Kim

Reformed Graduate University, Seoul

\section{Nietzsche Versus Paul, by Abed Azzam}

Insurrections: Critical Studies in Religion, Politics, and Culture | New York: Columbia University Press, 2015 | xx + 209 pages | ISBN: 978-0-23I-I6930-I (hardcover) \$90.00; ISBN: 978-0-23 I-I693 I-8 (softcover) \$30.00; ISBN: 978-0-23 I-538978 (ebook) \$29.99

Hampered by prose that is dense, sometimes turgid (and occasionally, for a run of paragraphs, often pages, the unkind might say, obscurantist), one is gripped

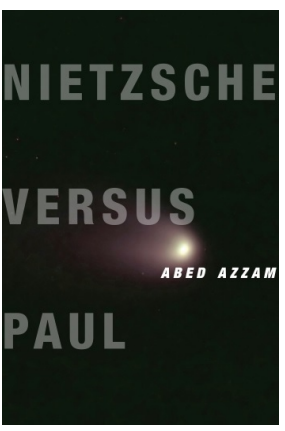
by a strong temptation to suspect that Abed Azzam's attempt to dislodge 
the time-honored reading of Nietzsche's (principally) philosophical anti-Plato stance, and to shunt it onto an Antichrist theological track located deep in the heart of orthodox Christian territory, is bound to fail. But perhaps this sort of premature response springs from an impatient, superficial reading? But why undertake such a difficult project in the first place if the "essential Nietzsche," on Azzam's own reading, is "impossible" to find? (xiii). Because rightly or wrongly, Azzam, convinced that Nietzsche's intentions are not simply driven by a Dionysian philosophy, claims to have discovered "an open historical horizon of Christianity" in the philosopher's works which "must challenge the prevailing view" (I47).

Abed Azzam's aims are as sweeping as they are ambitious. On the one hand, Nietzsche Versus Paul claims to be "a study of the Christian embrace of Nietzsche's sought-after truth that ends in its obliteration" (xii). On the other hand, the procedure which governs that study is shaped "as a reconstruction of the Nietzschean history of Christianity ... revolving around the question (of pessimism) about the meaning of suffering" with a view to:

(I) reintegrating into the discourse the "largely neglected" Nietzsche-Paul relationship (xvi);

(2) redressing the perceived oversight of Nietzsche's treatment of Christianity and Judaism;

(3) establishing the premise that the Nietzsche-Antichrist plumb line is far more important than "the anti-Platonic one" (xv);

(4) exposing "how Nietzsche's understanding of Socrates is one guided by his reading of Paul" (xix);

(5) expounding Nietzsche's critique of Modernity, famously its focus on the principle of "self-preservation" (xx).

Azzam appears to be confident that he has achieved his aims, and in addition claims:

(I) to have "located Nietzschean thinking in the bosom of Pauline theology, insofar as these... three parts match its triangle consisting of Christ, the Antichrist, and the Katechon" ( 146 ); 
(2) to have confirmed his understanding of the mutual cancellation of Heidegger's and Deleuze's readings of Nietzsche because both "delimit" themselves "to the horizon of the history of philosophy, or Nietzsche and the antiPlato" (I 47);

(3) and finally, to have successfully defined the significance of the Greek Dionysian origin in Nietzsche's thinking in the context of Christian/Pauline thinking, citing Karl Löwith's understanding of Nietzsche's "religiosity as being Christian and un-Greek" - while at the same time decrying Löwith's condemnation of Nietzsche's "departure from the path of philosophy and his taking of the Christian path," and Löwith's insistence on making "philosophy a constant and Christian variable" (I49).

Azzam is aware of the implications of such revisionist claims, but perhaps not the wrestling with mutually contradictory insights that comes with them, and more, the debates that will ensue over the notion that "Nietzsche's atheism is Christian and not Greek" (I 50 ). Intriguing as this assertion might be, his cause is not helped by the ambiguity and opacity of his conclusions (I 50 ):

(I) Nietzsche's Christian legitimization of the modern Antichrist brought him to the idea of the legitimacy of the origin as such;

(2) Nietzsche's innocent "I am" has the original faith of Abraham as its constitutive model;

(3) Insofar as Nietzsche's visible horizon could not extend beyond the repressed Greek Dionysus, Nietzsche becomes a questionable Dionysian philosopher.

In the end, we are left with these questions: has Azzam furthered a line of scholarship that emphasizes the significance of Paul for understanding Nietzsche's project? (or more pressingly) has he added anything new to the Nietzsche-Pauline contra? and, finally, has he convincingly argued his revisionist theses?

My reaction to Nietzsche Versus Paul oscillates from a feeling of strong irritation at times and deep misgivings, to an expectation that in amongst the opaqueness of its delivery lies something provocative, something that might 
even confirm my own revisionist understanding of Nietzsche. My intuition about this kept encouraging a more patient reading, for somehow there was a sense that here were the beginnings of a groundbreaking investigation, even though there were initial hurdles to overcome, as the following list of reservations illustrate.

First, Azzam draws attention to what might be called Nietzsche's tease provocation that, although the philosopher barely even knows himselfnever mind anyone else ("Es ist schwer zu erkennen, wer ich bin"), it nevertheless allows for the possibility that a "genius" might in a hundred years arise who really "knows" humankind and be (cap)able [inferred] of digging Mr F. N. out of his grave ("irgend ein Genie von Menschenkenner, welches Herrn F. N. ausgräbt": $K G B, 3.3$, Briefentwurf an Heinrich von Stein [Mitte März, I 885 ] 27). For me it was more than a tease: it is a provocation to follow Nietschze's's clues to a kind of El Dorado discovery of the missing pieces in his project, his Rätzel. So right from the start, Azzam signals that he is totally aware of the impossibility of such an enterprise, even if he is inspired and excited by it. Though paradoxically he has Heidegger and Deleuze agreeing "that an essential-Nietzsche ought to be sought" (xiv), possibly to strengthen his case against them as "partial readings" (xv). His categorical negation of their theses ("neither can be said to represent the essential-Nietzsche") and his argument by assertion as fact ("For the undeniable fact remains that the negative standpoint which Nietzsche's writings take is primarily that of the Antichrist and not that of the anti-Plato"; xv), however, places Azzam in a vulnerable position with quite some convincing to do. He goes on to say that "the possibility of fleshing out the essential Nietzsche cannot be made unless Nietzsche's Antichrist is first examined" (xv), so imposing even greater demands, and further raises the question as to why there should be this "shift away from philosophy to the history of Christianity" (xv).

Second, Nietzsche Versus Paul contends that because Nietzsche speaks of a "Dionysus versus the Crucified" that this must necessarily rule out the significance of the strong "pagan philosophical" roots going back to Plato and Socrates, something that surely must be contested when two other equally breath-taking assertions taken out of context from Nietzsche - that "Plato becomes a Christian before Christianity," and that Hegel becomes a Katechon (delayer) (xv) are also touted as factually true of Nietzsche's position.

Third, Nietzsche Versus Paul (at a time when the dialogue between theology and philosophy seems to be opening up) is determined to reignite the old controversies that followed in the wake of their divorce and to reintroduce 
the cloud of misunderstanding under which both disciplines have labored for a number of centuries, by his dismissive comments regarding philosophy's limited horizon. Such a stance is unhelpful.

Fourth, Azzam claims that, for Nietzsche, "the genuine character of Modernity ... [rests] on its discontinuity with Christianity" (xx), when the weight of scholarly opinion seems to lie with the conviction that Nietzsche's project defines Modernity as infected by the ressentiment of institutional Christianity. But, as a consequence of casting Nietzsche in the role of contesting within a theological and Christian framework, it is in Azzam's interest to "prove" that Nietzsche somehow sides with Christianity against Modernity's "idea of its own worldliness... grounded in the principle of self-preservation" (xx). And when Azzam adds to this the notion that somehow Nietzsche also sees Hegel as the delayer (Katechon) of atheism, while there may be some truth there, does this necessarily mean that Nietzsche's views correspond with $\mathrm{St}$ Paul's view of the Antichrist as understood from within a Christian context?

Azzam is certainly onto something by insisting on more of a "Christian" perspective than has often been admitted with Nietzsche-although even here there is a substantial body of work that would endorse it. Some authors and titles include: Giles Fraser, Redeeming Nietzsche: On the Piety of Unbelief; Tyler Roberts, Contesting Spirit: Nietzsche, Affirmation, Religion; Bruce Ellis Benson, Pious Nietzsche: Decadence and Dionysian Faith; Lippitt and Urpeth (eds.), Nietzsche and the Divine; Alistair Kee, Nietzsche Against the Crucified; Craig Hovey, Nietzsche and Theology; Stephen Williams, The Shadow of the Antichrist. However, caution is to be urged as to how this might be executed.

While agreeing that Nietzsche's audience is Christian, and his revisionist project arises from deep within a Christian theological framework, ${ }^{3}$ I don't believe it is necessary in so doing that we have to ditch philosophy or deny its Greek pagan antecedents by painting it over with a Christian veneer.

This review is not the occasion for an in-depth analysis of Azzam's revisionist claims, but certainly these claims will demand the close attention of those writing on Nietzsche's project in the future-as certainly will be the

\footnotetext{
${ }^{3}$ See Lucy Huskinson, An Introduction to Nietzsche (Baker Academic, 2009), xvii: "Nietzsche's target audience is Christian, and... his writings intend to provoke Christians with a timely wake-up call. In particular, it highlights those aspects of Nietzsche's critique of Christianity that expose problems within Christian discipleship, such as the common inability among Christians to comprehend the meaning of faith, and to realize how excruciatingly difficult and "serious it is both to live an authentically Christian life and to facilitate the life-enhancing force of Christianity."
} 
case for this reviewer. However, a general critique can be offered to pique the appetite of the casual and scholarly reader.

There are two central questions I would direct at Azzam's mind-bending work: why does it strive so passionately to situate Nietzsche within a "Christian" context; and why does it so vehemently oppose philosophy, when Azzam's exercise clearly is a struggle to make something fit that doesn't seem to fit, and more seriously, might actually distort Nietzsche's (philosophical, psychological and cultural) project in the process?

Azzam, naturally, would defend his thesis by arguing that it arises from Nietzsche's own words and declarations, which in fairness Azzam cites often and in detail. And certainly there is much to support his revolutionary claims in as far as the philosopher/psychologist is forever breaking the rules: behaving as a philosopher and so offending the philology establishment; then flouting the philosophers by "inventing" psychology; thumbing the nose at the Christian institutional Church of his day (Protestant and Lutheran and Catholic) together with the political institutions that are embedded with it; and indeed, turning his back on the academic establishment in general by becoming a "gypsy" thinker of no fixed abode. But the very nature of the constantly shifting sand of Nietzsche's positional thinking itself should be sufficient warning not to take any of the philosopher's pronouncements at face value, certainly not to take them out of context, with the even more urgent caveat, to account for the tone, style, and genre with which any of his declarations are made - not to mention rhetoric. Which, fair to say, Azzam rarely does. But then again, Tracy B. Strong may well be right to point out this is Nietzsche's problem as much as it is any commentator's insofar as Nietzsche's "rhetorical excesses" raise "the question of the responsibility of a writer for the unintended consequences that his writing permits" (Friedrich Nietzsche, International Library of Essays in the History of Social and Political Thought (Ashgate, 2009), xvii).

Nidesh Lawtoo, The Phantom of the Ego (Michigan State University Press, 2013) and Christa Acampora, Contesting Nietzsche (The University of Chicago Press, 20I 3) — both reasonably representative of sound Nietzschean scholarshipwould vigorously contest the assumptions upon which Azzam's premises are based. Their philosophical, psychological, cultural, and rigorously historical contextual approaches expose the shaky foundations upon which Azzam builds. Lawtoo's treatment locates the Nietzsche-Plato axis in the context of Nietzsche's discussion of Modernity. It goes something like this. There is a sickness of mind at the heart of modernism created by ressentiment. It is a 
Platonic and Wagnerian sickness: "a phantom of the ego," in fact a collective phantom which robs us of our authenticity, our individuality, our affirmation of life, our hope and our grip on reality generally. The central problem with which Nietzsche grapples is how to sustain a "pathos of distance" which prevents us from slipping into "self-dissolution" and the nightmare of "non being" and a loss of purpose, one of "being and not being a subject." Far from blunting his analysis, the inclusion of himself in Modernity's pathology, Lawtoo claims, sharpens Nietzsche's critical lens. Indeed, Lawtoo posits that Nietzsche's personal experience of Bayreuth leads him to the conclusion that Wagner and modernity are two sides of the same coin, the Bayreuth theatrical circle being the crucible in which Nietzsche's insights are forged. In sum, Lawtoo's Nietzsche is concerned with the critique of modernism which has little to do with Azzam's Pauline "Antichrist" as he explains it; though from this reviewer's perspective, the notion could be customized to accommodate the arrogance, deception, and accusatory spirit of the biblical Antichrist.

Thus, in sum, Nietzsche's preoccupation with Wagner and Plato from Lawtoo's perspective is profound, one from which it would be seemingly impossible to "shift" into something like a purely Antichrist justification based on Pauline theology. Yes, the Antichrist is important in the Nietzsche project; yes he would have been aware of St Paul as the "revaluator" of noblemorality-but none of these either individually or as a whole cancel out the vital connection with Dionysus, which Lawtoo defines as also being part and parcel of Modernity's neurosis. Lawtoo explains: "The Dionysian mimesis he had celebrated in his youth with Wagner, contra Plato, he now condemns as a sickness with Plato contra Wagner. This revaluation in Nietzsche's preoccupation with mimesis during his later period involves a shift of emphasis from aesthetics to morality" (Lawtoo, 65).

When we place Azzam's claims alongside Acampora's version of Nietzsche's contestation with Paul in the context of the agon once again we are caused to wonder about the stability and even the validity of Azzam's project. Under the section title, "Fighting to the Death: the Agonies Of Pauline Christianity," Acampora states that Nietzsche's attack on Pauline Christianity is an outgrowth of his struggle with Socrates, that in fact his case against Paul is like his case against Socrates in many ways, "except that Paul lacks some of Socrates's redeeming qualities," and claims that Paul remains Saul as a persecutor of God (Acampora, I I 2). Acampora goes on to note that "Nietzsche depicts [Pauline?] Christianity as complicit in bringing about its own destruction insofar as it sets up a contest as central to the meaning of what it 
is to be a good Christian, but the goal (eradicating what makes one a human being) undermines the very possibility of being a legitimate contestant for vying for the meaning of human existence" (Acampora, I I 5 ). In essence, Acampora argues that Nietzsche's reasons for "contesting" with Paul is that he illustrates a mode of destructive competitiveness that defeats the positive purposes of the agon, which is to ensure the health of the individual and the community. She notes that the words which Nietzsche uses for St Paul's struggle are drawn straight out of Luther's Bible, Wettkampf, and Kampf. In effect Acampora posits that Nietzsche sees Paul as heralding Christ's agonies which are actually not inherent in the original symbol of the figure of the Jesus of "glad tidings." And that Paul invests those agonies with a particularly potent significance that serves to elevate his own status. She goes on to say that in Nietzsche's account of "the genuine history of Christianity," he distinguishes Christian doctrine and dogma from the life of Christ: "in truth there was only one Christian and he died on the cross. The 'evangel' died on the cross. What has been called 'evangel' from that moment was actually the opposite of that which he lived: 'ill tidings,' a dysangel!" (Der Antichrist, 39).

Consequently, while it is possible to see that he was aware of Paul, it is quite impossible to fathom how Nietzsche, at least in Lawtoo's and Acompara's readings of him, would emulate Paul as a model. But maybe here is the rub: that as Nietzsche himself admitted, "The greatest part of our being is unknown to us.... We have a phantom of the 'ego' in our heads, which determines us many times over" (cited by Lawtoo from Nietzsche's Nachlass, I).

There is much to be gleaned from Azzam's work, for which it is to be prized, particularly its discovery of "an open historical horizon of Christianity" in Nietzsche's works which "must challenge the prevailing view" (I47), but perhaps not quite in the exact way Azzam was hoping for. For all of the difficulties both in terms of accessibility and argument, Nietzsche Versus Paul is worth the effort. I commend it as a challenging and intriguing exposition.

Nikolai Blaskow

Bangor University 